University of Rhode Island

DigitalCommons@URI

Open Access Master's Theses

2021

\title{
THE DIETARY INTAKE OF MALE AND FEMALE BODYBUILDERS DURING COMPETITION PREPARATION
}

Garrett Grill

University of Rhode Island, garrett_grill@uri.edu

Follow this and additional works at: https://digitalcommons.uri.edu/theses

\section{Recommended Citation}

Grill, Garrett, "THE DIETARY INTAKE OF MALE AND FEMALE BODYBUILDERS DURING COMPETITION PREPARATION" (2021). Open Access Master's Theses. Paper 1939.

https://digitalcommons.uri.edu/theses/1939

This Thesis is brought to you for free and open access by DigitalCommons@URI. It has been accepted for inclusion in Open Access Master's Theses by an authorized administrator of DigitalCommons@URI. For more information, please contact digitalcommons-group@uri.edu. 


\title{
THE DIETARY INTAKE OF MALE AND FEMALE \\ BODYBUILDERS DURING COMPETITION
}

\author{
PREPARATION
}

BY

GARRETT GRILL

\section{A THESIS SUBMITTED IN PARTIAL FULFILLMENT OF THE \\ REQUIREMENTS FOR THE DEGREE OF \\ MASTER OF SCIENCE \\ IN \\ KINESIOLOGY}

UNIVERSITY OF RHODE ISLAND

2021 


\title{
MASTER OF SCIENCE THESIS
}

OF

\section{GARRETT GRILL}

\begin{abstract}
APPROVED:
Thesis Committee:

Major Professor Disa Hatfield

Matthew Delmonico

Kathleen Melanson

Brenton DeBoef

DEAN OF THE GRADUATE SCHOOL
\end{abstract}

UNIVERSITY OF RHODE ISLAND

2021 


\begin{abstract}
Background The growing popularity of the sport of bodybuilding has led to the creation of new categories such as men's physique, classic physique, figure, fitness, and bikini where little is known of the dietary strategies of these newer divisions. The primary aim of this study was to assess the kcal and macronutrient intake of bodybuilders during three time points of competition preparation and distinguish these strategies between divisions.
\end{abstract}

Methods This observational cross-sectional study consisted of one hundred fortyfive participants (90 men aged $31.5 \pm 8.9$ and 55 women aged $31.7 \pm 7.4$ ). Participants completed a modified version of the Dietary Assessment of a Natural Bodybuilding Population Questionnaire which has been used in previous research assessing diet during three time points. At each time point, participants recorded dietary intake over a 24-hour period. Participants were categorized according to their competitive division and grouped together for dietary analysis (Bodybuilding: BB, Men's Physique: MP, and Women's Divisions: WD). Kcal and macronutrient analysis was performed using MyFitnessPal. Repeated measures analysis of variance (ANOVA) was used to examine and compare the kcal and macronutrient intake expressed in grams and $\mathrm{g} / \mathrm{kg}$ bodyweight between competitive divisions during the three time points of competition preparation. Significance was set at $p \leq 0.05$.

Results Mean kcal and macronutrient intake in all groups significantly decreased from the initial to end time period $(p \leq 0.05)$. Mean kcal intake of BB was significantly greater than MP and WD at all time periods $(p \leq 0.05)$. Mean kcal intake of MP was significantly greater than WD at all time periods $(p \leq 0.05)$. Mean $\mathrm{CHO}$ 
intake of BB was significantly greater compared to MP and WD at all time points $(p \leq$ 0.05). Mean $\mathrm{CHO}$ intake of MP was significantly greater compared to WD only at the initial time point of competition preparation $(p \leq 0.05)$. Mean PRO intake of BB was significantly greater than WD at all time points $(p \leq 0.05)$. Also, mean PRO intake of MP was significantly greater than WD at all times points $(p \leq 0.05)$. Fat (g/kg BW) intake was significantly greater in BB compared to WD at all time points $(p \leq 0.05)$.

Conclusions Competitors in the bodybuilding division consumed a greater amount of kcals and carbohydrates throughout the entirety of competition preparation compared to other divisions. Greater kcal and carbohydrate intake could theoretically be contributed to greater muscle mass and starting weight as different divisions place different expectations on competitors. To the best of our knowledge, this is the first study to differentiate dietary strategies between competitive divisions. However, future research is needed to increase generalizability for all divisions. 


\section{ACKNOWLEDGMENTS}

First, I would like to thank and express gratitude to my supervisor, Dr. Disa Hatfield, who has provided me with guidance and continuous support throughout this project. Thank you for agreeing to take me on as a student and turning my idea into reality. Without your persistent help, the goal of this project would not have been achieved. You allowed me to form my own hypothesis and take my research in an independent direction.

I would like to thank the members of my committee, including Dr. Matthew Delmonico and Dr. Kathleen Melanson. To Dr. Delmonico, thank you for steering me in the right direction and always keeping your door open whenever I needed additional support. To Dr. Melanson, thank you for agreeing to serve on my committee. Your enthusiasm in the field of nutrition is admirable and your insightful comments and participation helped finalize this project. Additionally, thank you to $\mathrm{Dr}$. $\mathrm{Xu}$ for taking time out of your schedule to chair my thesis defense.

Also, I would like to thank my undergraduate assistant, Nick Abbatangelo. Thank you for taking the time to help me with data collection. You made the process easier and it was a pleasure to work with you.

Finally, I would like to acknowledge my family and express great appreciation for their unconditional love and support throughout my years of study at the University of Rhode Island. This accomplishment would not have been possible without them and I cannot put into words how fortunate I am to have them in my life. 


\section{TABLE OF CONTENTS}

ABSTRACT ................................................................................................................ ii

ACKNOWLEDGMENTS ....................................................................................... iv

TABLE OF CONTENTS................................................................................... v

LIST OF TABLES ....................................................................................................... vi

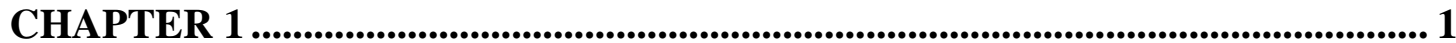

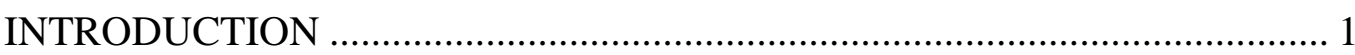

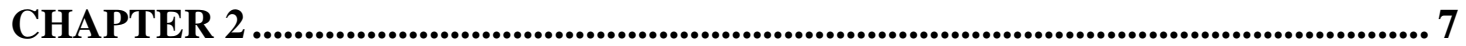

REVIEW OF LITERATURE …................................................................. 7

CHAPTER 3 ....................................................................................................................... 18

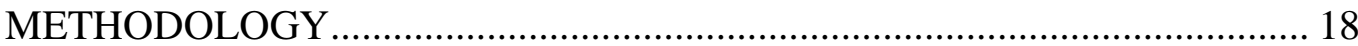

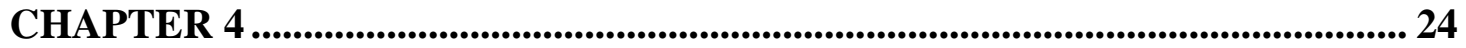

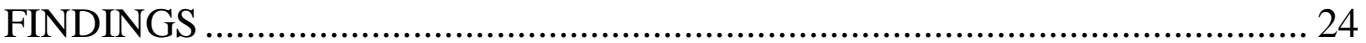

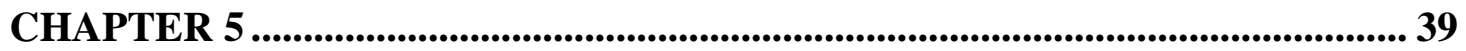

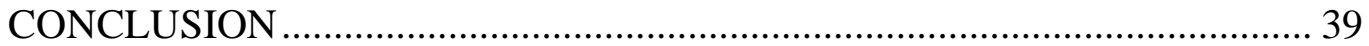

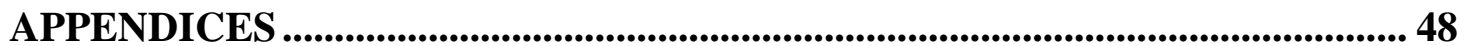

BIBLIOGRAPHY ............................................................................................................... 59 


\section{LIST OF TABLES}

TABLE

PAGE

Table 1. Participant Characteristics of Competitive Groups.................................. 25

Table 2. Participant Characteristics of Men's Physique Competitors ......................... 26

Table 3. Participant Characteristics of Bikini Competitors ...................................... 27

Table 4. Participant Characteristics of Figure Competitors ..................................... 28

Table 5. Participant Characteristics of Classic Physique Competitors ...................... 29

Table 6. Participant Characteristics of Bodybuilding Competitors ............................ 30

Table 7. Participant Characteristics of Fit Body Competitors................................. 31

Table 8. Participant Characteristics of Wellness Competitors ….............................. 32

Table 9. Participant Characteristics of Women's Physique Competitors .................... 33

Table 10. Participant Characteristics of Fitness Competitors ................................. 34

Table 11. Mean Kcal and Macronutrient Intake of Competitive Groups ................... 37

Table 12. Macronutrient and Energy Intake Scaled to Starting BW of Competitive

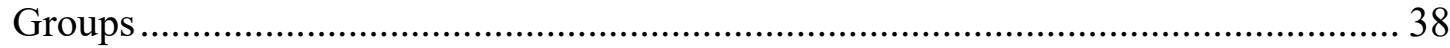




\section{CHAPTER 1}

\section{INTRODUCTION}

Bodybuilding is the process of developing the musculature of the body through specific types of resistance training and dietary strategies, especially for competitive exhibition (7). During bodybuilding competitions, bodybuilders appear in lineups and perform specified poses for a panel of judges who rank them based on muscle mass, symmetry, stage presentation, and overall physical aesthetics (19). During competition preparation, bodybuilders typically consume a high protein and caloric restricted diet with the aim of achieving drastic reductions in body fat while maintaining their lean body mass (7).

The growing popularity of the sport of bodybuilding has led to the creation of new categories such as men's physique, classic physique, figure, fitness, and bikini (22). These newer categories have different lean and muscularity ideals for stage presentation. For example, the Mr. Olympia competition introduced a new category for men in 2013, one that aims to attract competitors with less extreme physiques (22). In the bodybuilding division, competitors aim to achieve maximum lean body mass, muscularity, and vascularity (having many prominent superficial veins) with body fat percentages ranging from 2-6\% for men and 6-11\% for women (14). On the contrary, competitors in newer divisions such as men's physique, aim to present a high level of muscularity and lean body mass but not as much as bodybuilders with moderate vascularity objectively determined by low body fat and low retained water, typically 
falling between a body fat range of 4-9\% (14). These guidelines are the same for women in the newer divisions of figure and fitness, however these competitors typically range from $8-15 \%$ body fat (14). On the other hand, the bikini division is judged by the most subjective rules where competitors aim to reach a moderate level of muscularity with some leanness and little vascularity ranging between $8-15 \%$ body fat (14). Furthermore, greater participation in bodybuilding competitions has been associated with more women within the newer categories (22).

The data in the sport of traditional bodybuilding have revealed that higher placing bodybuilders followed a high-protein and low-fat diet and consumed more carbohydrates than their less successful peers (4). However, there is insufficient quantities of research on bodybuilders (4). While a meta-analysis combined 18 separate studies on the dietary intake of traditional bodybuilders, the majority of the studies were published in the 1980s and 1990s and were non-specific about participants' divisions and phase of competition preparation (22). This review provides insights into dietary practices of competitive bodybuilders such as the carbohydrate intakes were below and protein intakes were above the current recommendations for strength athletes in men (22). Additionally, the most commonly reported dietary supplements were protein powders or liquids (22). However, the studies failed to provide details on the rationale for different dietary intakes and the authors acknowledged the need for further investigation into the topic (22). This review demonstrated that the literature on the dietary practices of bodybuilders during competition preparation is dated and of poor quality (22). 
While there is limited research on the newer divisions in the sport of bodybuilding, there is some research examining nutrient intakes for bodybuilders (1). Current peer-reviewed recommendations are that caloric intake should be set at a level that results in bodyweight reduction of approximately 0.5 to $1 \%$ per week to maximize muscle retention (5). This caloric intake has been associated with bodybuilders responding best to consuming $2.3-3.1 \mathrm{~g} / \mathrm{kg}$ of lean body mass per day of protein, $15-$ $30 \%$ of calories from fat, and the remainder of calories from carbohydrate (7). Additionally, eating four to six meals per day each containing $0.4-0.5 \mathrm{~g} / \mathrm{kg}$ bodyweight of protein is likely to maximize any benefits from nutrient timing and frequency (17). Although suggestions exist for nutrient intakes (10), these recommendations are not specific to the different competitive divisions and are open to interpretation (9). In conjunction, these dietary practices employed by bodybuilders in the newer categories have not been scrutinized (9).

In addition to a paucity of research concerning dietary strategies between competitive divisions, current data on bodybuilding are disproportionately focused on men and not women (1). Also, macronutrient intake may be different between categories due to various reasons including body composition and overall competitive goal (1). The majority of studies fail to provide detailed information on the dietary strategies during competition preparation and the most prevalent peaking strategies used by bodybuilders are unreported in the current literature (14). Consequently, evidence exists that a number of dietary strategies used by bodybuilders may be detrimental to health such as water restriction and electrolyte manipulation and that 
these practices are increasingly becoming more popular (7), further highlighting the need to examine this association between the newer competitive divisions.

Although traditional bodybuilding has developed over the years and there is some research, many dietary strategies of modern bodybuilders lack scientific scrutiny, especially during competition preparation (3). Most information on the topic is anecdotal, with limited research about the nutritional habits of modern bodybuilders from newer categories (12). The lack of research on the practices employed within the newer divisions, may mislead bodybuilders as to what the most effective strategies are for competition preparation (3). One area that is unexplored is the breakdown and comparison of macronutrient intake, fluid intake, supplementation, and peaking strategies between the newer competitive divisions (12).

In the week prior to competition, bodybuilders employ tapering strategies for the body in attempt to maximize their competition day aesthetics (2). Known as "peak week" these strategies involve the manipulation of macronutrients, electrolytes, water, and exercise (2). The main goals of "peak week" are to maximize glycogen stores by optimally storing carbohydrates within muscle tissue, minimize subcutaneous fat, and minimize abdominal bloating via fiber restriction (2). However, different competitive divisions place different expectations on the athlete, which is likely to influence competition preparation and peaking strategies (18). These variables include the amount of carbohydrates consumed during peak week, nutrient timing, and water restriction (2).

There is no research of the comparison in these dietary strategies between the newer divisions in the sport of bodybuilding (5). Primarily, the current research is 
restricted to small cross-sectional or case studies (5). Additionally, there is a lack of large-scale studies on competitive bodybuilders (7). The small number of participants does not allow for generalization; therefore, it is unconfirmed if the majority of bodybuilders between divisions adopt the same or similar dietary strategies (4). Data observing a larger number of competitors, each from different categories would add to the present analysis (7). Furthermore, additional research is required to better understand the role of dietary and peaking strategies in the bodybuilding culture (2).

Research examining macronutrients, fluid intake, supplementation, and peaking strategies between competitive divisions is imperative for employing evidence-based recommendations. Measuring kcal and macronutrient intake has been associated with weight change, indicating the unique role it may play in one's competition preparation (9). Further research examining the dietary strategies of competitors in the new categories at multiple time points during competition preparation is needed to further our understanding of their practices (12). Understanding the association of dietary strategies within newer competitive divisions would allow researchers to determine if evidence-based recommendations may provide better alternatives to allow this population to achieve their desired results more effectively.

Therefore, the primary aim of this study is to assess the kcal and macronutrient intake of bodybuilders during competition preparation and distinguish these strategies between divisions. The secondary aim is to examine these changes over three time periods within each division. We hypothesize that competitors in the bodybuilding division will consume a greater amount of protein, carbohydrates, and fat due to their 
larger body mass throughout the entirety of competition preparation compared to other divisions. 


\section{CHAPTER 2}

\section{REVIEW OF LITERATURE}

\section{Traditional Bodybuilder Studies}

A systematic review was done (Spendlove et al., 2015) that assessed the dietary practices of competitive bodybuilders with the objective to identify gaps in the literature. This study reviewed 18 studies with a total of 385 participants divided into 323 men (aged $26.9 \pm 4.7)$ and 62 women (aged 28.6 \pm 4.2$)(22)$. Studies had to describe macronutrient consumption and participants had to be engaged in training for amateur or professional bodybuilding competitions across any category. Results showed that total protein intake ranged from 1.9 to $4.3 \mathrm{~g} / \mathrm{kg} /$ day for men and from 0.8 to $2.8 \mathrm{~g} / \mathrm{kg} / \mathrm{day}$ for women (22). Additionally, total carbohydrate intake ranged from 3.0 to $7.2 \mathrm{~g} / \mathrm{kg} /$ day for men and from 2.8 to $7.5 \mathrm{~g} / \mathrm{kg} /$ day for women (22). Also, total fat intake across the studies ranged from 19 to $241 \mathrm{~g} /$ day for men and 9 to $124 \mathrm{~g} / \mathrm{day}$ for women (22). Furthermore, total kcals consumed by men competitors were divided up as $52 \%$ of that energy coming from carbohydrates, $28 \%$ from protein, and $22 \%$ from fat (22). Total kcals consumed by women competitors were divided up as 59\% energy from carbohydrate, $28 \%$ from protein, and $12 \%$ from fat (22).

However, this research has limitations including the majority of studies were published in the 1980s and 1990s. During competition preparation, competitors may be consuming more protein now compared to traditional dietary strategies used in the past. Also, evidence was not specific to a time period such as the off-season or in- 
season phase, which can greatly impact macronutrient consumption for competitive bodybuilders. The study emphasized that many of these dietary strategies lack scientific scrutiny and that a deeper approach to evaluate the nutritional intake of bodybuilders is needed (22). Furthermore, little is known about women and the newer bodybuilding categories (22). This evidence highlights the needs to compare caloric and macronutrient intake between competitive divisions. Overall, the main finding of this study was that high quality research is needed in the area of dietary intake of bodybuilders with the potential to uncover strategies worthy of scientific exploration (22).

Additional evidence was presented (Lambert et al., 2004), that evaluated the literature and provided recommendations for dietary macronutrient composition and total energy intake for bodybuilders during the off-season and pre-contest phases. This research concluded that there is evidence that a relatively high protein intake $(30 \%$ of energy intake) will reduce lean mass loss relative to a lower protein intake (15\% of energy intake) (11). The higher protein intake will also provide a relatively large thermic effect that may aid in reducing body fat (11). The thermic effect is a metabolic response in which food intake results in an increase in energy expenditure due to the various steps of nutrient processing (15). Additionally, the researchers suggested that the composition of diets for bodybuilders should be 55-60\% carbohydrates, $25-30 \%$ protein, and 15-20\% fat, for both the off-season and pre-contest phases (11). In the off-season, the diet should be slightly increased (15\% increase in energy intake) and during the pre-contest phase the diet should be decreased (15\% decrease in energy intake) (11). While this study provided macronutrient recommendations for 
bodybuilders, it did not take into consideration each competitive division and their own dietary strategies.

\section{Modern Bodybuilder Studies}

A study was done (Chappell et al., 2018) that investigated the nutritional strategies of high-level natural bodybuilders during competition preparation. This study utilized a cross-sectional design with 51 participants including 35 men (aged $32.2 \pm 14$ ) and 16 women (aged $34.4 \pm 10.2$ ) who competed at the British Natural Bodybuilding Federation (BNBF) finals (3). Participants were instructed to complete a 34-item questionnaire assessing their diet at three time points. During each time point, participants recorded their food intake over a 24-hour period. Participants were assigned to two groups: "placed" (meaning the competitor finished in the top five) and "non-placed" (meaning the competitor finished outside of the top five). The study found that total carbohydrate, protein, and fat intake decreased over three time points in both men and women cohorts $(p<0.05)(3)$. Additionally, men participants reduced their carbohydrate intake on average from 4.4 to $4.1 \mathrm{~g} / \mathrm{kg}$ compared to women participants from 3.9 to $3.3 \mathrm{~g} / \mathrm{kg}$ (3). Also, there were similar starting points of fat intake $(0.8 \mathrm{~g} / \mathrm{kg})$ for men and women with only a small reduction at the end of competition preparation among women $(0.6 \mathrm{~g} / \mathrm{kg})(3)$. Furthermore, placed men competitors consumed more carbohydrates at the start of competition preparation $(5.1$ vs $3.7 \mathrm{~g} / \mathrm{kg} \mathrm{BW})$ than non-placed competitors $(\mathrm{d}=1.02,95 \% \mathrm{CI}[0.22,1.80])(3)$. While this study compared macronutrient intake between placed vs. non-placed men and women competitors, the dietary recall only incorporated a single day of food intake on three separate time points. Furthermore, all men participants competed in the 
bodybuilding category while the women participants were recruited from three categories. However, no specific comparisons were made between each category.

Further research evidence was presented (Chappell et al., 2019) that compared the nutritional strategies of British professional (PRO) and amateur (AMA) natural bodybuilders during competition preparation. This study utilized a cross-sectional design that consisted of 47 competitors ( 33 men aged $30.9 \pm 8.7$ and 14 women aged $39.4 \pm 9.5$ ) recruited from the BNBF regional qualifiers and the Drug Free Athletes Coalition (DFAC) British PRO Grand Prix during 2017. The men cohort included 8 PROs and 25 AMAs whereas the women cohort included 5 PROs and 9 AMAs (4). Participants completed a 34-item questionnaire (Dietary Assessment of a Natural Bodybuilding Population) on their dietary strategies at three time points: start, middle, and end phase of their competition diet. Results demonstrated a significant reduction in energy and macronutrients as competition preparation increased in both men and women (all $p<0.05)(4)$. Additionally, total carbohydrate and energy intake was higher in PRO men compared to AMA men (100 grams and $400 \mathrm{kcals}$ or greater) at all time points of their competition diet $(p<0.05)(4)$. Limitations of this research include the lack of comparison between competitive divisions and the schedule of the participants was not assessed, which may have influenced the time spent in the offseason or in-season phase (4).

Another study was done (Ismaeel et al., 2018) that assessed the nutritional habits of competitive bodybuilders and compared the nutrient intakes of macronutrient-based dieting and strict dieting individuals. Macronutrient-based dieting was defined as a nutrition strategy that focuses on individual macronutrient intake 
whereas strict dieting was defined as following a restricted diet with specific foods and portion sizes (9). Data from 41 participants (30 men aged $29.3 \pm 7$ and 11 women aged $28.8 \pm 7.3$ years) were used in analyses (9). Participants completed a comprehensive food questionnaire and diets were analyzed using a computer system. Men consumed an average of 2,577.2 $\mathrm{kcal}(\mathrm{SD}=955.1)$ with an average fat intake of $83.6 \mathrm{~g}$, average carbohydrate intake of $323.3 \mathrm{~g}$, and an average protein intake of $163.4 \mathrm{~g}(9)$. No significant differences were found between men macronutrient-based dieting and strict dieting bodybuilders when compared for all nutrients (9). On the contrary, women consumed an average of $1,794 \mathrm{kcal}(\mathrm{SD}=453.1)$ with an average fat intake of $58.3 \mathrm{~g}$, average carbohydrate intake of $217.8 \mathrm{~g}$, and an average protein intake of $103.8 \mathrm{~g}(9)$. For men, macronutrient-based dieters consumed significantly greater amounts of protein, vitamin E, K, and C (9). The study concluded that competitive bodybuilders should be advised to take their micronutrition into greater consideration as over half of the participants consumed less than the recommended amounts. Similar to previous research, participants were not compared between competitive divisions.

Additional research reviewed (Iraki et al., 2019) the scientific literature on dietary topics related to bodybuilders during the off-season in order to provide practical recommendations. The authors recommendations were as follows: 1) bodybuilders in the off-season should focus on consuming a slightly hyper-energetic diet (10-20\% above maintenance calories) with the aim of gaining $0.25-0.5 \%$ of bodyweight per week, 2) dietary protein intake is recommended to be $1.6-2.2 \mathrm{~g} / \mathrm{kg} /$ day with a focus on sufficient protein at each meal $(0.40-0.55 \mathrm{~g} / \mathrm{kg} / \mathrm{meal})$ with an even distribution throughout the day (3-6 meals), 3) dietary fats should be consumed at 
moderate levels, neither too low or high $(0.5-1.5 \mathrm{~g} / \mathrm{kg} /$ day $), 4)$ all remaining calories should come from carbohydrates while ensuring sufficient amounts are consumed (>3.5 g/kg/day) (8). The authors emphasized for additional research on bodybuilders on a large-scale basis (8). The small number of participants in current research does not allow for generalization; therefore, it is unconfirmed if the majority of bodybuilders between divisions adopt the same or similar dietary strategies (4). Additionally, data from this study are only focused on the off-season phase. This evidence highlights the need for further research on bodybuilders between divisions during the in-season phase.

A systematic review (Helms et al., 2014) examined scientific literature relevant to competition preparation on nutrition and supplementation of natural bodybuilders in order to provide evidence-based recommendations. Electronic databases such as PubMed, MEDLINE, SPORTDiscus, and CINAHL were searched online for key words associated with calories and macronutrients. Each publication selected was carefully screened for studies that included healthy humans in a caloric deficit. After analyzing selected publications, the authors concluded that caloric intake should be set at a level that results in bodyweight loss on average of 0.5 to $1 \% /$ wk to maximize muscle retention (7). Additionally, the authors recommend that it may be best to pursue a gradual approach to weight loss towards the end of competition preparation compared to the beginning to avoid lean body mass loss in terms of caloric intake (7). Regarding protein intake, this review states most but not all bodybuilders will respond best to consuming 2.3-3.1 g/kg of lean body mass per day of protein (7). Regarding fat intake, the authors suggest a lower end consumption of $15-20 \%$ of calories from fat 
can be appropriate if higher percentages would reduce carbohydrate or protein ideal ranges (7). If not, 15-30\% of calories should come from fat (7). Regarding carbohydrate intake, the authors suggest the reminder of calories should come from carbohydrates (7). Similar to other research, the authors emphasized the lack of largescale studies on competitive bodybuilders and the data relevant to natural bodybuilding are extremely limited (7). This evidence highlights the need for further research regarding the kcal and macronutrient intake of competitive bodybuilders within the newer divisions during competition preparation to better understand their dietary strategies.

\section{Physique Athlete Studies}

A study was done (Gentil et al., 2017) that reported and analyzed the practices adopted by bodybuilders to propose evidence-based alternatives. This observational case series interviewed six participants (four men aged $23.7 \pm 4$ and two women aged $29.5 \pm 7.7)$ and asked them to describe in detail their nutritional practices. Participants consisted of two men's physique competitors, two bodybuilders, and two wellness competitors. Participants were analyzed for body composition before and after the bulking and cutting phases. During the bulking phase, bodybuilders aim to increase muscle mass without gaining unnecessary body fat (8). In comparison, the goal of the cutting phase is to achieve drastic reductions in body fat while maintaining muscle mass (7). This study found that bodybuilders ingested $\sim 2.5 \mathrm{~g}$ of protein $/ \mathrm{kg}$ of bodyweight during the bulking phase compared to $\sim 3 \mathrm{~g} / \mathrm{kg}$ of bodyweight during the cutting phase (6). Also, $15 \%$ of calories came from fat and carbohydrate consumption decreased by $10-20 \%$ during the cutting phase (6). This study concluded that high 
protein intakes $(2.5 \mathrm{~g} / \mathrm{kg} \mathrm{BW})$ are not obligatory to preserve lean mass while losing fat making it beneficial for people who do not tolerate severe restrictions in carbohydrate or fat intake (6). Limitations of this research include the very small sample size and therefore does not allow for generalization. The need for a larger study with more participants from each division is imperative for a comprehensive understanding of these dietary strategies (6).

More evidence was presented (Lenzi et al., 2019) that evaluated the dietary strategies of bodybuilders in the men's physique division during different time periods of the in-season phase. This study was a prospective study with a quasi-experimental design. Sixteen men's physique competitors (aged $29 \pm 6$ years) took part in the study and completed an in-person questionnaire describing their dietary and training habits throughout competition preparation (12). Additionally, nutritional intake was assessed by three 24-hour food diaries undertaken on three separate days. Dietary analysis revealed a low carbohydrate intake (below 6-10 g/kg BW) during bulking with a further decrease $(p<0.05)$ during cutting (12). Additionally, carbohydrate consumption consisted of $261 \mathrm{~g}(2.98 \mathrm{~g} / \mathrm{kg})$ during the bulking phase and $178 \mathrm{~g}$ $(2.3 \mathrm{~g} / \mathrm{kg})$ during the cutting phase (12). A significant decrease occurred from bulking to cutting phases in absolute and relative energy intake $(p=0.003)(12)$. During the cutting phase, protein intake (grams) was $273.29 \pm 105.40$ and fat intake (grams) was $49.09 \pm 29.12($ all $p<0.05)(12)$.

This study demonstrates strong evidence for those competing in the new competitive category of men's physique. However, it contained a small sample size and the use of 24-hour food diaries can be considered a potential limitation due to 
underreporting and overreporting (12). This is a concern of the 24-hour dietary assessment because data generated by this method may not represent the long-term dietary strategies of the competitor (16). Additionally, this study emphasized the need for further examination of the dietary strategies of competitors in the newer divisions to further understand their practices and help them achieve their goals more effectively (12).

A systematic review was done (Roberts et al., 2020) that provided nutritional recommendations for physique athletes. The goal of that review was to provide nutritional guidelines for men and women physique athletes during competition preparation and the recovery period. Long-term human studies were primarily selected for nutrition and macronutrient intake from the electronic databases PubMed, SPORTDiscus, Google Scholar, and MEDLINE. Based on the evidence from each study, the authors suggested a protein intake of $1.8-2.7 \mathrm{~g} / \mathrm{kg} / \mathrm{day}$ or up to $3.5 \mathrm{~g} / \mathrm{kg} / \mathrm{day}$ for those trying to mitigate hunger (17). Additionally, recommendations of carbohydrate intake should be adjusted in order for training performance to be optimized while consuming adequate caloric intake to reach the desired physique (17). This means that competitors should allow for what calories remain in the "energy budget" to come from carbohydrates to combat the negative impact of caloric restriction and weight loss on training performance (17). Therefore, the authors recommended men and women physique athletes to consume $2-5 \mathrm{~g} / \mathrm{kg}$ per day to reach the desired level of leanness with the majority of carbohydrates coming from whole grains, fruits, and vegetables (17). The authors recommended that a fat intake of 10$12 \%$ will allow for individual variability and dietary flexibility yet they advise caution 
for very low-fat intake for long periods of time (17). The authors emphasized additional study of physique athletes is needed to provide more specific guidelines (17). These data highlight the need for further research on kcal and macronutrient consumption between divisions in the sport of bodybuilding in order to provide specific guidelines for each category.

\section{Discussion / Future Directions}

Cumulatively, these data from each study indicates that there is a need for additional research on the dietary strategies of bodybuilders within the newer divisions. Current evidence demonstrates that a wide range of carbohydrate and fat intake is typically consumed by physique athletes (17). The consumption of macronutrients varies widely across competitors and the current phase of competition preparation in which intake occasionally falls outside the recommended ranges. Furthermore, greater participation in bodybuilding competitions has been associated with more women within the newer categories (22). This emphasizes the need for more research on women bodybuilders during competition preparation.

Dietary fat intake has been previously recommended as a lower level of 15-20\% of total calories for bodybuilders (7). However, it is unlikely all competitors stay within this range during competition preparation as levels are as low as $\sim 9 \%$ (17). Major issues in the current literature include the lack of large-scale studies which does not allow for generalization and the lack of research on the newer bodybuilding categories. As the sport of bodybuilding has grown, the newer categories of men's physique, classic physique, figure, fitness, and bikini present different ideals for stage presentation. There are multiple factors to consider when determining the kcal and 
macronutrient intake of bodybuilders during competition preparation and these variables highly depend on the individual and what division the competitor is competing in. Currently, there is no research that has examined and compared the kcal and macronutrient intake of bodybuilders according to the multiple divisions within the sport. Research examining these dietary strategies between competitive divisions is required to greater understand these practices and may uncover alternative recommendations through future evidence to help competitors reach their results more effectively. 


\section{CHAPTER 3}

\section{METHODOLOGY}

\section{Observational Approach to the Problem}

The dietary intake of male and female bodybuilders during competition preparation, a cross-sectional study, began in 2020 under the direction of principal investigator, Disa Hatfield, PhD. Data were collected using a modified version of the Dietary Assessment of a Natural Bodybuilding Population Questionnaire that has been used in previous research (4). All recorded information was not able to readily identify each participant and was stored electronically in one folder on one password protected computer in Dr. Hatfield's locked office. Missing questionnaire data and clarification of strategies were followed up via email. This research was approved by the University of Rhode Island Institution Review Board (Reference \#: 1650638-2).

\section{Participants}

Participants read and signed an IRB-approved informed consent form before agreeing to participate in the study. Participants were asked to provide as much detail as possible on the questionnaire assessing their diet at three time points during competition preparation.

One hundred forty-five participants were needed to appropriately assess the study aim of examining the kcal and macronutrient intake (protein: PRO, carbohydrate: $\mathrm{CHO}$, and fat) of men and women competitive bodybuilders between divisions. This number allowed us to gain at least 10 participants in most competitive 
divisions and account for incomplete data and participant drop-out. This study used a purposeful sampling technique to recruit men and women competitive bodybuilders in any division between the ages of 18 and 62 years old. Participants must have competed in a bodybuilding competition in the past or is currently in preparation for their first competition. Participants were recruited by word-of-mouth, social media postings, email, and text message. Participants that were interested in the study were assessed for inclusion and exclusion criteria and if deemed eligible, they completed the modified version of the Dietary Assessment of a Natural Bodybuilding Population Questionnaire. Exclusion criteria included failure to participate in a bodybuilding competition or not falling between the specified age range.

Study location: All study procedures took place electronically via the internet through email, social media, and online forms.

\section{Procedures}

IRB-Approved Informed Consent: All participants received and signed an informed consent form before agreeing to participate in the study regarding the purpose, procedures, risks, and benefits of participating in this proposed study. Modified Version of the Dietary Assessment of a Natural Bodybuilding Population Questionnaire: This questionnaire has been used in previous research in which significant differences $(p<0.05)$ of carbohydrate and energy as well as a difference $(p$ $<0.03$ ) in the estimated energy deficit were recorded between professional men and amateur bodybuilding competitors (4). Additionally, the questionnaire was used in another study (2) where the findings are in agreement with previous research which reported a similar focus on carbohydrate, water, and sodium manipulation during peak 
week amongst bodybuilders (13). Participants were instructed to provide as much detail as possible for each section on the questionnaire.

- Competitor Information: Participants were instructed to complete this section of the questionnaire and provide information regarding their bodybuilding division, years training, weeks dieting for competition, current weight at the start of competition preparation, and current weight at the end of competition preparation. Body fat percentage and the method used to estimate was recorded if it was known by the participant.

- Fluid Intake: Participants were instructed to complete this section of the questionnaire and provide information regarding their daily fluid intake recorded in ounces, the use of artificial sweeteners or sugar free drinks, and other beverage intakes according to the given options on the questionnaire and record how many times per day, week, or month each beverage was consumed during competition preparation.

- Supplementation: Participants were instructed to complete this section of the questionnaire and provide information regarding their supplement intake by marking what supplements they used according to the given options on the questionnaire and record the brand name of each supplement if it is known.

- Dietary Approach: Participants were instructed to complete this section of the questionnaire and provide information regarding their diet style. Diet style included clean eating (consuming whole foods and avoiding processed foods), if it fits your macros (IIFYM), and cheat meals. Protein, fat, and carbohydrate 
consumption were recorded as high, medium, or low during competition preparation. High, medium, and low were up to participant interpretation.

- Competition Diet: Participants were instructed to complete this section of the questionnaire and provide information regarding their foods and beverages consumed and record them in either portion sizes, ounces, or grams at three time points during their competition preparation. This included their initial diet (first few weeks), middle diet (halfway phase), and end diet (final weeks). Refeed and cheat meals were assessed by asking participants how many times per week on average these meals were consumed and to provide what they ate and the nutritional facts of the meal if possible.

- Peaking Strategies: This was assessed by instructing participants to check what peaking strategy they used according to the given options on the questionnaire and provide detail including food types, number of days, amount, and timing.

- Competition Day Plan: This was assessed by instructing participants to check what competition day strategy they used according to the given options on the questionnaire and provide detail including food types, amount, timing before stepping on stage, and brand used. Additionally, one item on the questionnaire asked about the duration of time used to "pump up" before going on stage.

- Resistance Training Program: Participants were instructed to complete this section of the questionnaire and provide information regarding their resistance training regimen according to the given options during three time points of their competition preparation. This included the first few weeks, halfway phase, and final weeks. 
- Cardiovascular Training Program: Participants were instructed to complete this section of the questionnaire and provide information regarding their cardiovascular training regimen according to the given options during three time points of their competition preparation. This included the first few weeks, halfway phase, and final weeks.

Pre-recorded Dietary Records: Participants were asked to voluntarily provide their pre-recorded dietary records that they followed during their competition preparation. These data were not used for the purpose of this thesis, instead it was used to help establish the validity and reliability of the main outcomes (kcal and macronutrient intake) on the questionnaire for the different competitive divisions.

Diet History Questionnaire (DHQIII) Survey (Past Month with Portion Size):

Participants were asked to voluntarily complete the DHQIII survey. These data were not used for the purpose of this thesis, instead it was used to help establish the validity and reliability of the main outcomes (kcal and macronutrient intake) on the questionnaire for the different competitive divisions.

Rights and Permissions: The Dietary Assessment of a Natural Bodybuilding Population Questionnaire was distributed under the terms of the Creative Commons Attribution 4.0 International License (http://creativecommons.org/licenses/by/4.0/) which permits unrestricted use, distribution, and reproduction in any medium. We would like to acknowledge the authors Dr. Chappell, Dr. Simper, and Dr. Helms from previous research (4) for allowing this questionnaire to be used. Changes made to the original questionnaire include: front cover modifications to match the purpose of this study, removal of competitor number and smoking status questions, changed 
measurement units ( $\mathrm{kg}$ to $\mathrm{lbs}, \mathrm{cm}$ to in, $\mathrm{ml}$ to oz), added refeed / cheat meals question, added peaking strategies and contest day plan page from a previous version of the questionnaire (2), included "pump up" question, and modified resistance training program questions.

\section{Statistical Analysis}

SPSS 27 statistical software by IBM in Armonk, New York was used for data analysis in this study. Men participants were grouped together and women participants were grouped together due to the various numbers of competitors in each division (Bodybuilding: BB, Men's Physique: MP, and Women's Divisions: WD). Participants were grouped together based on homogenous characteristics and we did not have sufficient power to compare the individual dietary intakes of each division. A $p$-value of less than or equal to 0.05 was used as a level of significance. Nutrient analysis was performed using MyFitnessPal by Under Armour in San Francisco, California.

Repeated measures analysis of variance (ANOVA) was used to examine and compare the association of kcals and macronutrients (dependent variables) expressed in grams between competitive divisions (independent variables) during the three time points of competition preparation. Additionally, repeated measures ANOVA with the Bonferroni correction was used to examine and compare the association of the macronutrient $(\mathrm{g} / \mathrm{kg})$ and energy intake $(\mathrm{kcal} / \mathrm{kg})$ scaled to the starting bodyweight of the competitive groups. All statistical analysis was performed in Independence Square at the University of Rhode Island. 


\section{CHAPTER 4}

\section{FINDINGS}

\section{Participant Characteristics}

One hundred forty-five participants (90 men aged $31.5 \pm 8.9$ and 55 women aged $31.7 \pm 7.4)$ were recruited and data from one hundred thirty-seven participants $(5.5 \%$ decrease) were used in statistical analysis due to participant drop-out and incompletion of the Dietary Assessment of a Natural Bodybuilding Population Questionnaire. There was a $2.2 \%$ decrease in men participants and a $10.9 \%$ decrease in women participants. This may be due to the cancellation of bodybuilding competitions during the time of data collection. Bodybuilding (BB) included 38 men competitors in the bodybuilding division. Men's Physique (MP) included 50 competitors: 34 men's physique and 16 classic physique. Women's Divisions (WD) included 49 competitors: 34 bikini, 9 figure, 3 women's physique, 1 wellness, 1 fitness, and 1 fit body. Participant characteristics between each division are presented in the following tables (Table 1: competitive groups, Table 2: men's physique, Table 3: bikini, Table 4: figure, Table 5: classic physique, Table 6: bodybuilding, Table 7: fit body, Table 8: wellness, Table 9: women's physique, Table 10: fitness). 
Table 1: Participant Characteristics of Competitive Groups

\begin{tabular}{|c|c|c|c|c|c|c|}
\hline \multirow[b]{2}{*}{ Variable } & \multicolumn{2}{|c|}{$\begin{array}{c}\text { Group 1 } \\
\text { Bodybuilding (BB) } \\
\text { N }=38\end{array}$} & \multicolumn{2}{|c|}{$\begin{array}{c}\text { Group 2 } \\
\text { Men's Physique (MP) } \\
\text { N }=\mathbf{5 0}\end{array}$} & \multicolumn{2}{|c|}{$\begin{array}{c}\text { Group } 3 \\
\text { Women's Divisions (WD) } \\
\mathrm{N}=49\end{array}$} \\
\hline & Mean & $\mathrm{SD} \pm$ & Mean & $\mathrm{SD} \pm$ & Mean & SD \pm \\
\hline Age (years) & 34.7 & 9.8 & 29.3 & 7.5 & 31.7 & 7.4 \\
\hline Height (cm) & 174.1 & 7.1 & 177.1 & 7.2 & 162.8 & 7.2 \\
\hline $\begin{array}{c}\text { Start Weight } \\
(\mathrm{kg})\end{array}$ & 88.5 & 11.8 & 90.1 & 10.1 & 61.5 & 6.6 \\
\hline $\begin{array}{c}\text { Stage Weight } \\
(\mathrm{kg})\end{array}$ & 76.4 & 10.8 & 78.2 & 9.3 & 52.8 & 5.4 \\
\hline Weight loss (\%) & 13.6 & 4.4 & 13.2 & 4.1 & 13.8 & 5.2 \\
\hline Years training & 13.7 & 10.1 & 8.3 & 8.0 & 5.4 & 4.6 \\
\hline Years competing & 7.3 & 6.6 & 4.4 & 7.1 & 3.7 & 4.4 \\
\hline $\begin{array}{c}\text { Competitions } \\
\text { this season }\end{array}$ & 2.0 & 1.3 & 1.4 & 0.8 & 2.0 & 1.6 \\
\hline $\begin{array}{l}\text { Diet Length } \\
\text { (weeks) }\end{array}$ & 23.1 & 10.1 & 19.7 & 11.1 & 24.5 & 12.9 \\
\hline $\begin{array}{c}\text { Start BMI } \\
(\mathrm{kg} / \mathbf{m} 2)\end{array}$ & 29.2 & 3.5 & 28.7 & 2.9 & 23.2 & 2.1 \\
\hline $\begin{array}{c}\text { Stage BMI } \\
(\mathrm{kg} / \mathrm{m} 2)\end{array}$ & 25.2 & 2.9 & 24.9 & 2.7 & 19.9 & 1.9 \\
\hline
\end{tabular}

Abbreviations: $\mathrm{BMI}=$ body mass index, $\mathrm{SD}=$ standard deviation. 
Table 2: Participant Characteristics of Men's Physique Competitors

\begin{tabular}{|c|c|c|}
\hline Variable & $\mathbf{N}=34 \quad$ Mean & $\mathbf{S D} \pm$ \\
\hline Age (years) & 28.8 & 7.5 \\
\hline Height (cm) & 177.1 & 7.2 \\
\hline Start Weight (kg) & 88.8 & 9.4 \\
\hline Stage Weight (kg) & 76.8 & 8.7 \\
\hline Weight loss (\%) & 13.4 & 4.3 \\
\hline Years training & 7.4 & 6.9 \\
\hline Years competing & 3.7 & 5.7 \\
\hline $\begin{array}{l}\text { Competitions this } \\
\text { season }\end{array}$ & 1.4 & 0.8 \\
\hline $\begin{array}{l}\text { Diet Length } \\
\text { (weeks) }\end{array}$ & 19.5 & 11.5 \\
\hline $\begin{array}{l}\text { Start BMI } \\
(\mathrm{kg} / \mathrm{m} 2)\end{array}$ & 28.3 & 3.0 \\
\hline $\begin{array}{l}\text { Stage BMI } \\
(\mathrm{kg} / \mathrm{m} 2)\end{array}$ & 24.5 & 2.7 \\
\hline
\end{tabular}

Abbreviations: $\mathrm{BMI}=$ body mass index, $\mathrm{SD}=$ standard deviation. 
Table 3: Participant Characteristics of Bikini Competitors

\begin{tabular}{|c|c|c|c|}
\hline Variable & $\mathbf{N}=34$ & Mean & $\mathrm{SD} \pm$ \\
\hline Age (years) & & 30.1 & 5.4 \\
\hline Height (cm) & & 164.6 & 7.3 \\
\hline Start Weight (kg) & & 61.2 & 7.2 \\
\hline Stage Weight (kg) & & 52.1 & 5.7 \\
\hline Weight loss (\%) & & 14.5 & 5.6 \\
\hline Years training & & 4.5 & 3.0 \\
\hline Years competing & & 2.7 & 2.0 \\
\hline $\begin{array}{l}\text { Competitions this } \\
\text { season }\end{array}$ & & 2.1 & 1.8 \\
\hline $\begin{array}{l}\text { Diet Length } \\
\text { (weeks) }\end{array}$ & & 25.1 & 13.1 \\
\hline $\begin{array}{l}\text { Start BMI } \\
(\mathrm{kg} / \mathrm{m} 2)\end{array}$ & & 22.5 & 1.8 \\
\hline $\begin{array}{l}\text { Stage BMI } \\
(\mathrm{kg} / \mathrm{m} 2)\end{array}$ & & 19.2 & 1.6 \\
\hline
\end{tabular}

Abbreviations: $\mathrm{BMI}=$ body mass index, $\mathrm{SD}=$ standard deviation . 
Table 4: Participant Characteristics of Figure Competitors

\begin{tabular}{|c|c|c|}
\hline Variable & $\mathbf{N}=\mathbf{9} \quad$ Mean & $\mathbf{S D} \pm$ \\
\hline Age (years) & 32.4 & 10.9 \\
\hline Height (cm) & 159.7 & 5.9 \\
\hline Start Weight (kg) & 64.1 & 5.5 \\
\hline Stage Weight (kg) & 55.4 & 4.0 \\
\hline Weight loss (\%) & 13.3 & 3.7 \\
\hline Years training & 7.6 & 8.2 \\
\hline Years competing & 6.3 & 8.7 \\
\hline $\begin{array}{l}\text { Competitions this } \\
\text { season }\end{array}$ & 1.7 & 0.9 \\
\hline $\begin{array}{l}\text { Diet Length } \\
\text { (weeks) }\end{array}$ & 21.7 & 12.4 \\
\hline $\begin{array}{l}\text { Start BMI } \\
(\mathrm{kg} / \mathrm{m} 2)\end{array}$ & 25.1 & 2.3 \\
\hline $\begin{array}{l}\text { Stage BMI } \\
(\mathrm{kg} / \mathrm{m} 2)\end{array}$ & 21.7 & 1.5 \\
\hline
\end{tabular}

Abbreviations: $\mathrm{BMI}=$ body mass index, $\mathrm{SD}=$ standard deviation. 
Table 5: Participant Characteristics of Classic Physique Competitors

\begin{tabular}{|c|c|c|c|}
\hline Variable & $N=16$ & Mean & $\mathrm{SD} \pm$ \\
\hline Age (years) & & 30.1 & 7.8 \\
\hline Height (cm) & & 177.1 & 7.3 \\
\hline Start Weight (kg) & & 93.1 & 10.9 \\
\hline Stage Weight (kg) & & 81.3 & 10.1 \\
\hline Weight loss (\%) & & 12.7 & 3.6 \\
\hline Years training & & 10.2 & 9.9 \\
\hline Years competing & & 5.9 & 9.4 \\
\hline $\begin{array}{l}\text { Competitions this } \\
\text { season }\end{array}$ & & 1.4 & 0.8 \\
\hline $\begin{array}{l}\text { Diet Length } \\
\text { (weeks) }\end{array}$ & & 20.2 & 10.5 \\
\hline $\begin{array}{l}\text { Start BMI } \\
(\mathrm{kg} / \mathrm{m} 2)\end{array}$ & & 29.6 & 2.5 \\
\hline $\begin{array}{l}\text { Stage BMI } \\
(\mathrm{kg} / \mathrm{m} 2)\end{array}$ & & 25.8 & 2.4 \\
\hline
\end{tabular}

Abbreviations: $\mathrm{BMI}=$ body mass index, $\mathrm{SD}=$ standard deviation . 
Table 6: Participant Characteristics of Bodybuilding Competitors

\begin{tabular}{|c|c|c|}
\hline Variable & $\mathbf{N}=38 \quad$ Mean & $\mathbf{S D} \pm$ \\
\hline Age (years) & 34.7 & 9.8 \\
\hline Height (cm) & 174.1 & 7.1 \\
\hline Start Weight (kg) & 88.5 & 11.8 \\
\hline Stage Weight (kg) & 76.4 & 10.8 \\
\hline Weight loss (\%) & 13.6 & 4.4 \\
\hline Years training & 13.7 & 10.1 \\
\hline Years competing & 7.3 & 6.6 \\
\hline $\begin{array}{l}\text { Competitions this } \\
\text { season }\end{array}$ & 2.0 & 1.3 \\
\hline $\begin{array}{l}\text { Diet Length } \\
\text { (weeks) }\end{array}$ & 23.1 & 10.1 \\
\hline $\begin{array}{l}\text { Start BMI } \\
(\mathrm{kg} / \mathrm{m} 2)\end{array}$ & 29.2 & 3.5 \\
\hline $\begin{array}{l}\text { Stage BMI } \\
(\mathrm{kg} / \mathrm{m} 2)\end{array}$ & 25.2 & 2.9 \\
\hline
\end{tabular}

Abbreviations: $\mathrm{BMI}=$ body mass index, $\mathrm{SD}=$ standard deviation. 
Table 7: Participant Characteristics of Fit Body Competitors

\begin{tabular}{|c|c|c|}
\hline Variable & $\mathbf{N}=1 \quad$ Mean & $\mathrm{SD} \pm$ \\
\hline Age (years) & 38 & \\
\hline Height (cm) & 156.2 & \\
\hline Start Weight (kg) & 59.4 & \\
\hline Stage Weight (kg) & 52.6 & \\
\hline Weight loss (\%) & 11.4 & \\
\hline Years training & 3.5 & \\
\hline Years competing & 3.5 & \\
\hline $\begin{array}{l}\text { Competitions this } \\
\text { season }\end{array}$ & 1.0 & \\
\hline $\begin{array}{l}\text { Diet Length } \\
\text { (weeks) }\end{array}$ & 28.5 & \\
\hline $\begin{array}{l}\text { Start BMI } \\
(\mathrm{kg} / \mathrm{m} 2)\end{array}$ & 24.3 & \\
\hline $\begin{array}{l}\text { Stage BMI } \\
(\mathrm{kg} / \mathrm{m} 2)\end{array}$ & 21.5 & \\
\hline
\end{tabular}

Abbreviations: $\mathrm{BMI}=$ body mass index, $\mathrm{SD}=$ standard deviation. 
Table 8: Participant Characteristics of Wellness Competitors

\begin{tabular}{|c|c|c|}
\hline Variable & $\mathbf{N}=1 \quad$ Mean & $\mathrm{SD} \pm$ \\
\hline Age (years) & 35.0 & \\
\hline Height (cm) & 160.0 & \\
\hline Start Weight (kg) & 64.4 & \\
\hline Stage Weight (kg) & 55.3 & \\
\hline Weight loss (\%) & 14.1 & \\
\hline Years training & 9.0 & \\
\hline Years competing & 1.0 & \\
\hline $\begin{array}{l}\text { Competitions this } \\
\text { season }\end{array}$ & 1.0 & \\
\hline $\begin{array}{l}\text { Diet Length } \\
\text { (weeks) }\end{array}$ & 52.0 & \\
\hline $\begin{array}{l}\text { Start BMI } \\
(\mathrm{kg} / \mathrm{m} 2)\end{array}$ & 25.1 & \\
\hline $\begin{array}{l}\text { Stage BMI } \\
(\mathrm{kg} / \mathrm{m} 2)\end{array}$ & 21.6 & \\
\hline
\end{tabular}

Abbreviations: $\mathrm{BMI}=$ body mass index, $\mathrm{SD}=$ standard deviation . 
Table 9: Participant Characteristics of Women's Physique Competitors

\begin{tabular}{|c|c|c|c|}
\hline Variable & $\mathbf{N}=\mathbf{3}$ & Mean & $\mathrm{SD} \pm$ \\
\hline Age (years) & & 43.6 & 3.5 \\
\hline Height (cm) & & 157.4 & 6.7 \\
\hline Start Weight (kg) & & 58.1 & 5.4 \\
\hline Stage Weight (kg) & & 53.2 & 8.2 \\
\hline Weight loss (\%) & & 8.6 & 5.7 \\
\hline Years training & & 8.3 & 3.5 \\
\hline Years competing & & 7.3 & 4.0 \\
\hline $\begin{array}{l}\text { Competitions this } \\
\text { season }\end{array}$ & & 2.3 & 0.5 \\
\hline $\begin{array}{l}\text { Diet Length } \\
\text { (weeks) }\end{array}$ & & 21.3 & 4.6 \\
\hline $\begin{array}{l}\text { Start BMI } \\
(\mathrm{kg} / \mathrm{m} 2)\end{array}$ & & 23.4 & 1.4 \\
\hline $\begin{array}{l}\text { Stage BMI } \\
(\mathrm{kg} / \mathrm{m} 2)\end{array}$ & & 21.4 & 2.5 \\
\hline
\end{tabular}

Abbreviations: $\mathrm{BMI}=$ body mass index, $\mathrm{SD}=$ standard deviation. 
Table 10: Participant Characteristics of Fitness Competitors

\begin{tabular}{|c|c|c|}
\hline Variable & $\mathbf{N}=1 \quad$ Mean & $\mathrm{SD} \pm$ \\
\hline Age (years) & 40.0 & \\
\hline Height (cm) & 154.9 & \\
\hline Start Weight (kg) & 57.6 & \\
\hline Stage Weight (kg) & 50.8 & \\
\hline Weight loss (\%) & 11.8 & \\
\hline Years training & 5.0 & \\
\hline Years competing & 5.0 & \\
\hline $\begin{array}{l}\text { Competitions this } \\
\text { season }\end{array}$ & 3.0 & \\
\hline $\begin{array}{l}\text { Diet Length } \\
\text { (weeks) }\end{array}$ & 12.0 & \\
\hline $\begin{array}{l}\text { Start BMI } \\
(\mathrm{kg} / \mathrm{m} 2)\end{array}$ & 23.9 & \\
\hline $\begin{array}{l}\text { Stage BMI } \\
(\mathrm{kg} / \mathrm{m} 2)\end{array}$ & 21.1 & \\
\hline
\end{tabular}

Abbreviations: $\mathrm{BMI}=$ body mass index, $\mathrm{SD}=$ standard deviation . 


\section{Kcal and Macronutrient Intake}

Mean kcal and macronutrient intake during the initial, middle, and end time periods of competition preparation for the competitive groups are reported in Table 11. Results of the repeated measures ANOVA identified a significant decrease in mean $\mathrm{kcal}$ and macronutrient intake in all groups over time from the initial to end time period $(p \leq 0.05)$. Mean kcal intake of BB was significantly greater than the mean kcal intake of MP and WD at all time periods of competition preparation $(p \leq 0.05)$. Also, mean kcal intake of MP was significantly greater than the mean kcal intake of WD at all time periods $(p \leq 0.05)$. Additionally, mean $\mathrm{CHO}$ intake of $\mathrm{BB}$ was significantly greater than the mean CHO intake of MP and WD at all time points $(p \leq 0.05)$. Furthermore, mean $\mathrm{CHO}$ intake of MP was significantly greater than the mean $\mathrm{CHO}$ intake of WD only at the initial time point of competition preparation $(p \leq 0.05)$. There were no significant differences seen among each group in absolute mean fat intake. Mean PRO intake of BB was significantly greater than the mean PRO intake of $\mathrm{WD}$ at all time points $(p \leq 0.05)$. Also, mean PRO intake of MP was significantly greater than the mean PRO intake of WD at all times points $(p \leq 0.05)$. However, mean PRO intake of BB did not significantly differ from MP at any time point.

Macronutrient and energy intake scaled to starting bodyweight of competitive groups during each diet phase is reported in Table 12. Results of the repeated measures ANOVA identified a significant decrease in energy (kcal/kg BW) in BB, MP, and WD from the initial to middle phase, middle to end phase, and initial to end phase $(p \leq 0.05)$. Also, BB significantly decreased $\mathrm{CHO}(\mathrm{g} / \mathrm{kg} \mathrm{BW})$ intake from the initial to middle phase and initial to end phase $(p \leq 0.05)$. Additionally, MP and WD 
significantly decreased $\mathrm{CHO}(\mathrm{g} / \mathrm{kg} \mathrm{BW})$ intake from the initial to middle phase, middle to end phase, and initial to end phase ( $p \leq 0.05)$. Fat ( $\mathrm{g} / \mathrm{kg} \mathrm{BW})$ intake was significantly greater in $\mathrm{BB}$ compared to $\mathrm{WD}$ at all time points $(p \leq 0.05)$. $\mathrm{BB}$ significantly decreased fat $(\mathrm{g} / \mathrm{kg} \mathrm{BW})$ intake from the initial to middle phase, middle to end phase, and initial to end phase ( $p \leq 0.05)$. In comparison, MP and WD significantly decreased fat ( $\mathrm{g} / \mathrm{kg} \mathrm{BW}$ ) intake from the initial to middle phase and initial to end phase $(p \leq 0.05)$. PRO $(\mathrm{g} / \mathrm{kg} \mathrm{BW})$ intake of BB and WD significantly decreased from the middle to end phase $(p \leq 0.05)$. There were no significant differences in PRO (g/kg BW) intake of MP. 
Table 11: Mean Kcal and Macronutrient Intake of Competitive Groups

\begin{tabular}{|c|c|c|c|c|c|c|c|c|c|c|c|c|c|}
\hline \multirow[b]{2}{*}{ Group } & \multirow[b]{2}{*}{$\mathbf{N}$} & \multicolumn{4}{|c|}{ Initial Phase } & \multicolumn{4}{|c|}{ Middle Phase } & \multicolumn{4}{|c|}{ End Phase } \\
\hline & & Kcals & $\begin{array}{c}\text { CHO } \\
(\mathrm{g})\end{array}$ & $\begin{array}{l}\text { Fat } \\
\text { (g) }\end{array}$ & $\begin{array}{l}\text { PRO } \\
(\mathrm{g})\end{array}$ & Kcals & $\begin{array}{c}\text { CHO } \\
\text { (g) }\end{array}$ & $\begin{array}{l}\text { Fat } \\
(\mathrm{g})\end{array}$ & $\begin{array}{c}\text { PRO } \\
(\mathrm{g})\end{array}$ & Kcals & $\begin{array}{c}\text { CHO } \\
\text { (g) }\end{array}$ & $\begin{array}{c}\text { Fat } \\
\text { (g) }\end{array}$ & $\begin{array}{l}\text { PRO } \\
\text { (g) }\end{array}$ \\
\hline $\begin{array}{l}\text { Bodybuilding } \\
\text { (BB) }\end{array}$ & 38 & $2836.2+$ & $309.9^{\wedge}$ & 104.6 & $203.0 \sim$ & 2474.1 & $243.3^{\wedge}$ & 88.6 & 199.9 & $2038.2 *$ & $190.2^{\wedge}$ & 72.4 & $188.6 \sim$ \\
\hline $\mathrm{SD} \pm$ & & 737.0 & 136.1 & 107.5 & 73.8 & 693.4 & 108.7 & 85.8 & 79.9 & 883.2 & 179.4 & 74.9 & 75.65 \\
\hline $\begin{array}{c}\text { Men's } \\
\text { Physique } \\
\text { (MP) }\end{array}$ & 50 & $2446.6+$ & 226.1- & 99.8 & $189.8 \sim$ & 2133.4 & 193.6 & 82.9 & 184.4 & $1739.4 *$ & 134.9 & 66.5 & $174.0 \sim$ \\
\hline $\mathrm{SD} \pm$ & & 1050.3 & 168.3 & 100.7 & 78.2 & 817.8 & 152.3 & 81.9 & 83.9 & 606.9 & 86.3 & 61.8 & 85.4 \\
\hline $\begin{array}{c}\text { Women's } \\
\text { Divisions } \\
\text { (WD) }\end{array}$ & 49 & $1729.7+$ & 161.2 & 75.2 & $134.9=$ & 1563.1 & 146.4 & 61.3 & $131.9=$ & $1352.6^{*}$ & 123.7 & 54.6 & $126.1=$ \\
\hline $\mathrm{SD} \pm$ & & 752.8 & 107.6 & 61.6 & 58.7 & 620.6 & 93.0 & 52.6 & 57.5 & 461.9 & 66.2 & 45.7 & 70.6 \\
\hline
\end{tabular}

Abbreviations: Kcals $=$ kilocalories, $\mathrm{CHO}=$ carbohydrate, $\mathrm{PRO}=$ protein, $\mathrm{SD}=$ standard deviation.

*Denotes mean kcal intake of BB is significantly greater than MP and WD at all phases $(p \leq 0.05)$.

+ Denotes significant decrease in kcal and macronutrient intake in all groups from the initial to end phase $(p \leq 0.05)$.

${ }^{\wedge}$ Denotes mean CHO intake of BB is significantly greater than MP and WD at all phases $(p \leq 0.05)$.

-Denotes mean CHO intake of MP is significantly greater than WD at the initial phase $(p \leq 0.05)$.

$\sim$ Denotes mean PRO intake of BB and MP is significantly greater than WD at all phases $(p \leq 0.05)$. $=$ Denotes mean PRO intake of MP is significantly greater than WD at all phases $(p \leq 0.05)$. 
Table 12: Macronutrient and Energy Intake Scaled to Starting BW of Competitive Groups

\begin{tabular}{|c|c|c|c|c|c|c|c|}
\hline \multirow[b]{2}{*}{ Variable } & \multicolumn{3}{|c|}{$\begin{array}{c}\text { Group } 1 \\
\text { Bodybuilding (BB) } \\
\mathbf{N}=38\end{array}$} & \multicolumn{2}{|c|}{$\begin{array}{c}\text { Group 2 } \\
\text { Men’s Physique (MP) } \\
\mathbf{N}=\mathbf{5 0}\end{array}$} & \multicolumn{2}{|c|}{$\begin{array}{c}\text { Group } 3 \\
\text { Women's Divisions (WD) } \\
\mathbf{N}=49\end{array}$} \\
\hline & $\begin{array}{c}\text { Diet } \\
\text { Phase }\end{array}$ & Mean & $\mathbf{S D} \pm$ & Mean & $\mathbf{S D} \pm$ & Mean & $\mathbf{S D} \pm$ \\
\hline \multirow{3}{*}{$\begin{array}{c}\text { Energy } \\
(\mathrm{kcal} / \mathrm{kg} \text { BW })\end{array}$} & Initial & $30.8^{*}$ & 10.4 & $27.9 *$ & 10.0 & $28.4 *$ & 12.4 \\
\hline & Middle & 27.1 & 9.8 & 25.6 & 9.6 & 24.3 & 9.9 \\
\hline & End & 21.7 & 7.5 & 22.4 & 6.4 & 19.4 & 7.2 \\
\hline \multirow{3}{*}{$\begin{array}{c}\text { CHO } \\
(\mathrm{g} / \mathrm{kg} \mathrm{BW})\end{array}$} & Initial & $2.6+$ & 1.1 & $2.9^{\wedge}$ & 1.5 & $2.8^{\wedge}$ & 2.2 \\
\hline & Middle & 2.1 & 1.1 & 2.6 & 1.5 & 2.3 & 1.8 \\
\hline & End & 1.8 & 1.5 & 2.2 & 1.1 & 1.5 & 0.9 \\
\hline \multirow{3}{*}{$\begin{array}{c}\text { Fat } \\
(\mathrm{g} / \mathrm{kg} \mathrm{BW})\end{array}$} & Initial & $1.6 \sim$ & 1.4 & 1.1 & 1.1 & 0.8 & 0.4 \\
\hline & Middle & 1.3 & 1.1 & 1.0 & 0.9 & 0.6 & 0.3 \\
\hline & End & 0.9 & 0.9 & $0.9=$ & 0.8 & $0.5=$ & 0.3 \\
\hline \multirow{3}{*}{$\begin{array}{c}\text { PRO } \\
(\mathrm{g} / \mathrm{kg} \mathrm{BW})\end{array}$} & Initial & 2.2 & 1.2 & 2.0 & 0.8 & 2.3 & 0.7 \\
\hline & Middle & $2.1>$ & 1.2 & 2.0 & 0.8 & $2.2>$ & 0.7 \\
\hline & End & 1.8 & 0.9 & 2.1 & 1.2 & 2.0 & 0.7 \\
\hline
\end{tabular}

Abbreviations: $\mathrm{BW}=$ bodyweight, $\mathrm{CHO}=$ carbohydrate, $\mathrm{PRO}=$ protein, $\mathrm{SD}=$ standard deviation.

$*$ Denotes significant decrease in energy in BB, MP, and WD from each diet phase $(p \leq 0.05)$.

+ Denotes BB significantly decreased CHO (g/kg BW) intake from initial to middle and initial to end phase $(p \leq 0.05)$.

${ }^{\wedge}$ Denotes MP and WD significantly decreased $\mathrm{CHO}(\mathrm{g} / \mathrm{kg} \mathrm{BW})$ intake from each diet phase $(p \leq 0.05)$.

-Denotes fat $(\mathrm{g} / \mathrm{kg} \mathrm{BW})$ intake of BB is significantly greater compared to WD at all phases $(p \leq 0.05)$.

$\sim$ Denotes BB significantly decreased fat $(\mathrm{g} / \mathrm{kg} \mathrm{BW})$ intake from each diet phase $(p \leq 0.05)$.

$=$ Denotes MP and WD significantly decreased fat $(\mathrm{g} / \mathrm{kg} \mathrm{BW})$ from initial to middle and initial to end phase $(p \leq 0.05)$.

$>$ Denotes PRO (g/kg BW) intake of BB and WD significantly decreased from the middle to end phase $(p \leq 0.05)$. 


\section{CHAPTER 5}

\section{CONCLUSION}

\section{Discussion}

In this investigation, we identified several significant differences in mean kcal, protein, and carbohydrate intake of BB compared to MP and WD. Additionally, we identified significant changes in mean kcal and macronutrient intake over three time points of competition preparation.

\section{Kcal Intake}

As expected, mean kcal and macronutrient intake of all groups was higher at the initial time point of competition preparation compared to the end time point. Similar findings have been reported in previous observations (22). On average, a significant decrease in mean kcal and macronutrient intake was identified in all groups from the initial time period to the end time period $(p \leq 0.05)$. BB consumed $2836.2 \pm 737 \mathrm{kcals}$ during the initial diet compared to $2474.1 \pm 693.4 \mathrm{kcals}$ during the middle diet whereas MP consumed 2446.6 \pm 1050.3 and $2133.4 \pm 817.8 \mathrm{kcals}$, and WD consumed $1729.7 \pm 752.8$ and $1563.1 \pm 620.6$ kcals respectively. This observation is similar to research done (Ismaeel et al., 2018) that assessed the nutritional habits of competitive bodybuilders. Men consumed an average of 2,577.2 kcals $(\mathrm{SD}=955.1)$ and women consumed an average of 1,794 kcals $(\mathrm{SD}=453.1)(9)$. Furthermore, our findings are consistent with previous research (Chappell et al., 2019) where competitors decreased their energy intake over three time points during competition preparation. This 
strategy of bodybuilders consuming less energy over time during the in-season phase is done to reduce body fat and achieve a lean physique (7).

Also, mean kcal intake of BB was significantly greater than the mean kcal intake of MP and WD at all time periods of competition preparation $(p \leq 0.05)$. Furthermore, mean kcal intake of MP was significantly greater than the mean kcal intake of WD at all time periods $(p \leq 0.05)$. This finding may represent some of the different requirements between each competitive division as they have different lean and muscularity ideals for stage presentation (19). Different physique classes place different expectations on their athletes, which likely influenced their practices during competition preparation (2). For example, competitors in the bodybuilding division aim to achieve maximum lean body mass, muscularity, and vascularity with body fat percentages ranging from $2-6 \%$ for men and $6-11 \%$ for women (14). On the contrary, competitors in newer divisions (men's physique, figure, and fitness) aim to present a high level of muscularity and lean body mass but not as much as bodybuilders with moderate vascularity typically falling between a body fat range of 4-9\% for men and 8-15\% for women (14). This evidence highlights the different expectations for competitors in each division as their goals depend on their different physique ideals for stage presentation.

\section{Carbohydrate Intake}

In the sport of bodybuilding, dietary strategies of high carbohydrate intake are considered to be the performance training standard (7). Carbohydrate intake for strength sports, including bodybuilding, is recommended to be between 4 to $7 \mathrm{~g} / \mathrm{kg}$ depending on the phase of training (21). Inadequate carbohydrate intake can impair 
strength training and reduce glycogen repletion (21). However, carbohydrate intake is customized to the individual and during bodybuilding competition preparation, intake is unlikely to be at the higher end of recommendations (7).

Carbohydrate was the most abundant macronutrient across all time periods and was reduced from the start to the end of competition preparation in all groups $(p \leq$ 0.05). Also, mean $\mathrm{CHO}$ intake of $\mathrm{BB}$ was significantly greater than the mean $\mathrm{CHO}$ intake of MP and WD at all time points $(p \leq 0.05)$. Furthermore, mean $\mathrm{CHO}$ intake of MP was significantly greater than the mean $\mathrm{CHO}$ intake of WD only at the initial time point of competition preparation $(p \leq 0.05)$. The present findings suggest that men bodybuilding, men's physique, and classic physique competitors consume more energy in the form of carbohydrates compared to bikini, figure, women's physique, wellness, fit body, and fitness competitors. These findings are consistent to research done (Ismaeel et al., 2018) where men competitors consumed a greater amount of carbohydrates $(323.3 \mathrm{~g}$ ) than women competitors (217.8g). Additionally, these findings may be contributed to the greater start weight and stage weight of BB and MP compared to WD as these competitors were able to consume more energy throughout competition preparation.

Moreover, mean CHO intake was between 2-3 g/kg scaled to starting bodyweight (BW) in all competitive groups at each time period. This relative mean $\mathrm{CHO}$ intake is in agreement with a previous recommendation that men and women physique athletes should consume $2-5 \mathrm{~g} / \mathrm{kg} \mathrm{BW}$ of $\mathrm{CHO}$ per day to reach their desired levels of leanness (17). Furthermore, Chappell (4) concluded that elite professional men bodybuilders consume more energy in the form of a diet consisting of higher carbohydrates 
compared to lower competitive levels. It may be beneficial to examine sugar, starch, and fiber consumption within mean $\mathrm{CHO}$ intake of each division. These data may allow for further differentiation of the dietary strategies between divisions and provide a rationale for carbohydrate manipulation strategies which have been examined in previous research (2). These strategies involve the restriction of carbohydrates for multiple days followed by increased carbohydrate consumption for multiple days with the goal of enhanced glucose transport and increased muscle glycogen supercompensation (20).

\section{Fat Intake}

Fat intake for competitive bodybuilders is typically emphasized on maintaining an adequate consumption while focusing on carbohydrates to fuel performance and protein to build and repair lean body mass (7). Bodybuilders are recommended to consider their dietary fat intake during competition preparation when attempting to preserve their muscle mass as evidence has shown low fat consumption negatively influences testosterone levels (11). Previously, it has been suggested that a fat intake of $15-20 \%$ of total calories for bodybuilders is appropriate if greater amounts would reduce protein and carbohydrate ideal ranges (11). Thus, this is an acceptable range of fat intake as low carbohydrate diets may negatively impact resistance training performance (21).

Fat was the lowest amongst the three macronutrients and was decreased over time in all groups during each time period of competition preparation $(p \leq 0.05)$. There were no significant differences between each group for absolute mean fat intake at each diet phase. However, relative mean fat intake (g/kg BW) was significantly 
greater in $\mathrm{BB}$ compared to WD at all time points $(p \leq 0.05)$. The absolute mean fat intakes recorded in the present study were $104.6 \mathrm{~g}, 88.6 \mathrm{~g}, 72.4 \mathrm{~g}(\mathrm{BB}), 99.8 \mathrm{~g}, 82.9 \mathrm{~g}$, 66.5g (MP), and 75.2g, 61.3g, 54.6g (WD) at the initial, middle, and end time points respectively. This decrease in fat intake is similar to the appropriate strategy that suggests bodybuilders respond best to consuming $15-30 \%$ of calories from fat (7).

In comparison, these findings are higher than previous accounts reported by Chappell (4) during each time period of competition preparation for men competitors and all but one time period for women competitors. The research done by Chappell (4) included professional and amateur competitors only recruited from the British Natural Bodybuilding Federation whereas the present study recruited participants from any bodybuilding federation. The different results in fat intake may be due to the different participant characteristics between the present study and research done by Chappell (4) as well as the differences that exist between competitors competing in the bodybuilding, men's physique, classic physique, or bikini divisions (12).

In comparison, mean fat intake during the middle time period in men and women participants (BB: $88.6 \mathrm{~g}$, MP: $82.9 \mathrm{~g}$, and WD: 61.3g) were similar to the men fat intake (83.6g) and women fat intake (58.3g) of competitors reported by Ismaeel (9). These findings may be due to the similar characteristics between participants in the present study and research done by Ismaeel (9) as both sample sizes consisted of competitive bodybuilders currently in competition preparation. Overall, more research is needed to assess the various fat intakes of competitors between divisions to determine significant differences. One unexplored area is the consumption between polyunsaturated and monounsaturated fats. 


\section{Protein Intake}

Adequate protein consumption during competition preparation is required to support the maintenance of lean body mass (7). Higher protein intakes are suggested for athletes to support increased levels of exercise and for weight lifters to support muscle growth (11). Research has suggested that a protein intake of 1.2 to $2.2 \mathrm{~g} / \mathrm{kg}$ is optimal to allow training adaptations for athletes who are consuming calories at or above their energy needs (23). However, bodybuilders restrict calories and achieve very lean physiques during competition preparation (7). Consequently, optimal protein intake for competitive bodybuilders may be higher than existing recommendations (7).

In the present study, mean PRO intake of BB was significantly greater than the mean PRO intake of WD at all time points $(p \leq 0.05)$. These protein intakes recorded (BB: 203g, 199.9g, 188.6g and WD: 134.9g, 131.9g, 126.1g) at the initial, middle, and end time points suggests that men bodybuilders consume more protein than women competitors during competition preparation. This finding is in agreement with results reported by Ismaeel where men competitors consumed a greater amount of protein (163.4g) compared to women competitors (103.8g) (9).

Furthermore, mean PRO intake of MP was significantly greater than the mean PRO intake of WD at all times points $(p \leq 0.05)$. This finding may be due to the greater amount of muscle mass and overall bodyweight in men's physique and classic physique competitors compared to women competitors. Each competitive group was consuming a minimum relative mean PRO intake of $1.8 \mathrm{~g} / \mathrm{kg} \mathrm{BW}$ during all time periods. This finding is in agreement with the recommendation by Roberts (17) that men and women physique athletes should consume $1.8-2.7 \mathrm{~g} / \mathrm{kg}$ BW of protein. 
Although the consumption of protein $(\mathrm{g} / \mathrm{kg} \mathrm{BW})$ in the present study is lower than bodybuilding recommendations of 2.3 to $3.1 \mathrm{~g} / \mathrm{kg}(7)$, it seems likely that all competitors were consuming enough protein for the preservation of muscle mass. Additionally, mean PRO intake of BB did not significantly differ from the mean PRO intake of MP at any time point. This result may be due to the similarities in start weight and stage weight between competitors in the bodybuilding, men's physique, and classic physique divisions.

\section{Limitations}

The present investigation is not without limitations. Primarily, there was not an equal number of participants in each competitive division which limits generalizability. An equal number of participants in each division would allow for increased generalizability as each dietary strategy would be individually analyzed. This evidence would allow researchers to find specific differences or similarities between each division instead of analyzing groups of competitors from multiple categories. Due to the unbalanced number in each division, participants were grouped together and we did not have sufficient power to compare the individual dietary intakes of each category.

Following a similar dietary plan for consecutive weeks is common in all competitors in the sport of bodybuilding (4) and underreporting is common in studies of dietary intake (12). However, bodybuilders are known for their careful nutritional tracking and adherence to their dietary plan (7). Furthermore, we only obtained information on participants' diet from three time points of competition preparation (start, middle, and end). Therefore, we were unable to capture any changes that may 
have occurred in-between those time periods. Additionally, we did not report participants' lean body mass or fat mass as this would have further differentiated each division. Finally, bodybuilders and coaches should be mindful that these strategies are only likely to be effective for competitors in the same division with a similar start weight and length of dieting for competition preparation.

\section{Conclusions / Practical Applications}

There are significant differences among each competitive group in mean kcal and macronutrient intake. Throughout the entirety of competition preparation, competitors in the bodybuilding division consumed a greater amount of kcals and carbohydrates compared to all other divisions.

To our knowledge, this is the first study to document and describe dietary strategies between competitive divisions in the sport of bodybuilding. Additionally, this study filled gaps in the current research where little is known about women and the newer bodybuilding categories (22). The findings of this study are likely to be of interest to competitive bodybuilders and coaches. However, these data should be interpreted with caution as most dietary plans are created on a one-on-one basis depending on the competitor's individual body adaptations. Our findings provide evidence in the current bodybuilding practices between divisions when competitors are grouped together. However, future research should focus on larger studies that incorporate an equal number of participants in each division. Data observing a larger and equal number of participants from each division would add to the present analysis and increase generalizability. An equal number of participants in each division would allow for their dietary strategies to be individually analyzed and this evidence could be 
used to demonstrate specific differences or similarities between kcal and macronutrient intake. 


\section{APPENDICES}

\section{APPENDIX A}

\section{Consent Form for Research}

\section{THE \\ UNIVERSITY}

OF RHODE ISLAND
IRB

Exempt Consent

Dr. Hatfield

Department of Kinesiology

Dietary Intake of Male and Female Bodybuilders during Competition Preparation

Page 1 of 2

You are being asked to take part in a research study. The purpose of the research study is to evaluate the dietary and nutritional supplementation strategies of bodybuilders on a large-scale basis in order to comprehensively provide a guide of their current practices during the "inseason" period leading up to a competition. Please read the following before agreeing to be in the study. If you agree to be in this study, you are confirming that you are a male or female that has competed or is currently competing in a bodybuilding competition. Additionally, you are confirming that you are at least 18 years old. It will take you approximately 20 minutes to complete this online survey in addition to providing your pre-recorded dietary records. Questions will be asked about dietary strategies, nutritional supplementation, and training during the "inseason" period leading up to a competition. Subjects who fully complete the online survey and provide their pre-recorded dietary records will be entered in a drawing to receive a $\$ 50$ Amazon gift card, with five winners selected in total. There are no known risks or compensation with participating in this study.

Your responses will be strictly confidential. The responses may be used in a research paper or thesis presentation.

The decision to participate in this study is entirely up to you. You may refuse to take part in the study at any time without affecting your relationship with the investigators of this study or the University of Rhode Island (URI). Your decision will not result in any loss of benefits to which you are otherwise entitled. You have the right not to answer any single question, as well as to withdraw completely from the survey at any point during the process; additionally, you have the right to request that the researchers not use any of your responses.

You have the right to ask questions about this research study and to have those questions answered by me before, during or after the research. If you have questions about the study, at any time feel free to contact Dr. Hatfield from the Department of Kinesiology at the University of Rhode Island (URI), at 401-874-2980.

Additionally, you may contact the URI Institutional Review Board (IRB) if you have questions regarding your rights as a research participant. Also contact the IRB if you have questions, complaints or concerns which you do not feel you can discuss with the investigator. The University of Rhode Island IRB may be reached by phone at (401) $874-4328$ or by e-mail at researchintegrity@etal.uri.edu. You may also contact the URI Vice President for Research and Economic Development by phone at (401) 874-4576.

Also, you will be asked to voluntarily fill out and complete the DHQIII survey (past month with portion size). This survey will take you approximately 45 minutes to complete. This is not required for full participation in this research study and you will still be entered in the $\$ 50$ Amazon gift card drawing if you choose not to complete it. 
THE

UNIVERSITY OF RHODE ISLAND

IRB

Exempt Consent

Page 2 of 2

Dr. Hatfield

Department of Kinesiology

Dietary Intake of Male and Female Bodybuilders during Competition Preparation

If you would like to keep a copy of this document for your records, please print or save this page now. You may also contact the researcher to request a copy.

By signing or typing your name below, you indicate that you have read and understood the above and volunteer to participate in this study.

Signature of Participant

Date

SEPTEMBER 2020 


\section{APPENDIX B}

\section{Advertisement / Recruitment Email}

THE

OF RHODE ISLAND
All Advertisements and Recruitment Emails

Dr. Hatfield

Department of Kinesiology

Dietary Intake of Bodybuilders during Competition Preparation

Page 1 of 1

Hello!

My name is Garrett Grill and I am a graduate student in the Kinesiology Department at the University of Rhode Island. I am working with Dr. Hatfield, the principal investigator, on a research study here at URI. The purpose of this study is to evaluate the dietary and nutritional supplementation strategies of male and female bodybuilders on a large-scale basis in order to provide a comprehensive guide on their current practices during competition preparation.

In order to be eligible to participate in this study, participants must be a male or female of at least 18 years old and have competed or are currently competing in a bodybuilding competition. There are no direct risks associated with participating in this online survey study, which would take no more than 20 minutes to complete.

Incentives: Participants who fully complete the online survey will be entered in a drawing to receive a $\$ 50$ Amazon gift card, with five winners selected in total. Additionally, another five participants who fully complete the online survey will be randomly selected to receive a free apparel item of choice from House of Pain Apparel.

This research has been approved by The University of Rhode Island Institutional Review Board.

If there are any questions about the study, please do not hesitate to contact us.

\section{Contact Information}

- Garrett Grill, garrett_grill@uri.edu, 845-216-7858

- Dr. Hatfield, doch@uri.edu, 401-874-5183

Thank you for your help!

Sincerely,

Garrett Grill \& Dr. Hatfield 
APPENDIX C

Dietary Assessment of a Natural Bodybuilding Population Questionnaire

\title{
Dietary Intake of Male and Female Bodybuilders during Competition Preparation Survey
}

\author{
THE \\ UNIVERSITY \\ OF RHODE ISLAND \\ Department of Kinesiology \\ Dr. Disa Hatfield \\ Garrett Grill
}


PLEASE ANSWER AII QUESTIONS RELATED TO YOUR COMPETITION PREPARATION

If you are unsure about any of the questions then please ask a researcher for clarification

\section{Competitor Information}

Competitor Class / Division:

Age:

Years bodybuilding training:

Years competing: Competitions this season:

Weeks dieting for this competition:

Current contest weight (lbs):

Weight at start of preparation (lbs):

Height (in):

Bodyfat $\%$ and the method used to estimate (leave blank if unsure):

Highest bodybuilding accolade (example: IFBB Pro Men's Physique Overall Champion 2020):

\section{Fluid Intake}

Typical daily fluid intake (ounces):

Do you use artificial sweeteners? Yes/No Do you use sugar free flavored drinks/syrup? Yes/No

Beverage intake during competition preparation, please mark $(X)$ as appropriate

\begin{tabular}{|l|c|c|c|c|c|c|c|c|c|}
\hline \multicolumn{7}{|c|}{ Standard Serving: can of soda 110z, cup of tea 5oz, take away coffee 8oz } \\
\hline Normal serving & $\begin{array}{c}\text { Less than } \\
\text { once a } \\
\text { month }\end{array}$ & $\begin{array}{c}1-3 \\
\text { per } \\
\text { month }\end{array}$ & $\begin{array}{c}1 \text { per } \\
\text { week }\end{array}$ & $\begin{array}{c}2-4 \\
\text { per } \\
\text { week }\end{array}$ & $\begin{array}{c}5-6 \\
\text { per } \\
\text { week }\end{array}$ & $\begin{array}{c}1 \text { per } \\
\text { day }\end{array}$ & $\begin{array}{c}2-3 \text { per } \\
\text { day }\end{array}$ & $\begin{array}{c}4-5 \text { per } \\
\text { day }\end{array}$ & $\begin{array}{c}6+\text { per } \\
\text { day }\end{array}$ \\
\hline Coffee & & & & & & & & & \\
\hline Espresso & & & & & & & & & \\
\hline Tea & & & & & & & & & \\
\hline Herbal tea & & & & & & & & & \\
\hline Energy drink & & & & & & & & & \\
\hline Fizzy drinks & & & & & & & & & \\
\hline Diet fizzy drinks & & & & & & & & & \\
\hline Alcohol & & & & & & & & & \\
\hline
\end{tabular}

Dietary Assessment Questionnaire

Version 09.30.2020 Page 2 


\section{Supplementation}

Supplement intake during competition preparation, please mark $(X)$ as appropriate

\begin{tabular}{|l|l|l|}
\hline Supplement & $\begin{array}{c}\text { please mark } \\
(\mathbf{\Xi})\end{array}$ & \\
\hline Multivitamin & & \\
\hline Vitamin C & & \\
\hline Vitamin D & & \\
\hline Mineral supplement & & \\
\hline Joint supplement & & \\
\hline Omega-3 / Cod liver oil & & \\
\hline Protein powder & & \\
\hline BCAA / EAA & & \\
\hline Individual amino acid & & \\
\hline Carbohydrate supplement & & \\
\hline Creatine (directly or indirectly) & & \\
\hline Fat burners & & \\
\hline Pre-workout supplements & & \\
\hline Protein bars & & \\
\hline Other & & \\
\hline
\end{tabular}

\section{Dietary Approach}

Which best describes your dietary approach? Circle or highlight where appropriate:
Diet Style: Clean eating
If it fits your macro's
Cheat meals

$\begin{array}{llll}\text { High: } & \text { Protein } & \text { Carbohydrate } & \text { Fat } \\ \text { Medium: } & \text { Protein } & \text { Carbohydrate } & \text { Fat } \\ \text { Low: } & \text { Protein } & \text { Carbohydrate } & \text { Fat }\end{array}$




\section{Competition Diet}

In the space below, please record the diet followed (in either portion sizes, ounces, or grams) at the start, middle and end (not including peak week) of your competition preparation. Please be as specific as possible.

\begin{tabular}{|c|c|c|}
\hline Initial Diet (f & Middle Diet (halfway phase) & End Diet (final weeks) \\
\hline $\begin{array}{l}\text { Example Diet } \\
\text { M1: } 3 \text { whole boiled eggs, } 1 \\
\text { banana } \\
\text { M2: } 40 \mathrm{~g} \text { whey protein shake, } 1 / 2 \\
\text { cup of oats, } 1 \text { tablespoon of all- } \\
\text { natural peanut butter } \\
\text { M3: } 6 \text { oz of grilled chicken, 3/4 } \\
\text { cup of white jasmine rice, } 1 \\
\text { cup of pineapple } \\
\text { M4 (pre training): } 6 \text { oz of } \\
\text { grilled chicken, } 1 \text { cup of white } \\
\text { jasmine rice, } 1.5 \text { tablespoons } \\
\text { of coconut oil } \\
\text { Pre-Workout: } 1 \text { scoop (19g) } \\
\text { of Cellucor C4 Ultimate icy } \\
\text { blue razz flavor } \\
\text { During Training: } 10 \mathrm{~g} \text { of } \\
\text { essential amino acids mixed } \\
\text { with water } \\
\text { M5: (post training): } 40 \mathrm{~g} \text { whey } \\
\text { protein shake, } 2 \text { cups of Reese's } \\
\text { puff cereal, } 1 \text { cup of sweetened } \\
\text { almond milk } \\
\text { M6: } 6 \text { oz of shrimp, } 1.5 \text { cups } \\
\text { of broccoli, } 6 \text { oz of white } \\
\text { potato } \\
\text { Drinks: } 2 \text { cups of instant black } \\
\text { coffee with meal } 1 \\
1 \text { can of Diet Coke }\end{array}$ & $\begin{array}{l}\text { Example Diet } \\
\text { M1: } 1 \text { whole boiled egg, } 1 \text { cup } \\
\text { of egg whites, } 1 \text { cup of } \\
\text { spinach } \\
\text { M2: } 40 \text { g whey protein shake, } \\
1 \text { tablespoon of all-natural } \\
\text { peanut butter } \\
\text { M3: } 6 \text { oz of grilled chicken, } 1 \\
\text { cup of green beans, } 1 / 2 \text { cup of } \\
\text { white jasmine rice } \\
\text { M4 (pre training): } 6 \text { oz of } \\
\text { grilled chicken, } 1 \text { cup of white } \\
\text { jasmine rice, } 1 \text { tablespoon of } \\
\text { coconut oil } \\
\text { Pre-Workout: } 1 \text { scoop (19g) } \\
\text { of Cellucor C4 Ultimate icy } \\
\text { blue razz flavor } \\
\text { During Training: } 10 \mathrm{~g} \text { of } \\
\text { essential amino acids mixed } \\
\text { with water } \\
\text { M5: (post training): } 40 \mathrm{~g} \text { whey } \\
\text { protein shake, } 1 \text { Thomas' whole } \\
\text { wheat bagel, } 1 \text { cup of } \\
\text { unsweetened almond milk } \\
\text { M6: } 6 \text { oz of shrimp, } 1.5 \text { cups } \\
\text { of broccoli, } 6 \text { oz of white } \\
\text { potato } \\
\text { Drinks: } 2 \text { cups of instant } \\
\text { black coffee with meal } 1 \\
1 \text { can of Diet Coke }\end{array}$ & $\begin{array}{l}\text { Example Diet } \\
\text { M1: } 1.5 \text { cups of egg whites, } 1 / 2 \\
\text { cup of oats } \\
\text { M2: } 40 \mathrm{~g} \text { whey protein shake, } 1 \\
\text { tablespoon of all-natural peanut } \\
\text { butter } \\
\text { M3: } 6 \text { oz of grilled chicken, } 1 \\
\text { cup of green beans, } 1 / 2 \text { cup of } \\
\text { white jasmine rice } \\
\text { M4 (pre training): } 6 \text { oz of } \\
\text { grilled chicken, } 1 \text { cup of white } \\
\text { jasmine rice } \\
\text { Pre-Workout: } 1 \text { scoop (19g) of } \\
\text { Cellucor C4 Ultimate icy blue } \\
\text { razz flavor } \\
\text { During Training: } 10 \mathrm{~g} \text { of } \\
\text { essential amino acids mixed } \\
\text { with water } \\
\text { M5: (post training): } 40 \mathrm{~g} \text { whey } \\
\text { protein shake, } 1 \text { cup of pineapple } \\
\text { M6: } 6 \text { oz of shrimp, } 1.5 \text { cups } \\
\text { of broccoli } \\
\text { Drinks: } 2 \text { cups of instant black } \\
\text { coffee with meal } 1 \\
1 \text { can of Diet Coke }\end{array}$ \\
\hline
\end{tabular}

Dietary Assessment Questionnaire

Version 09.30.2020 Page 4 


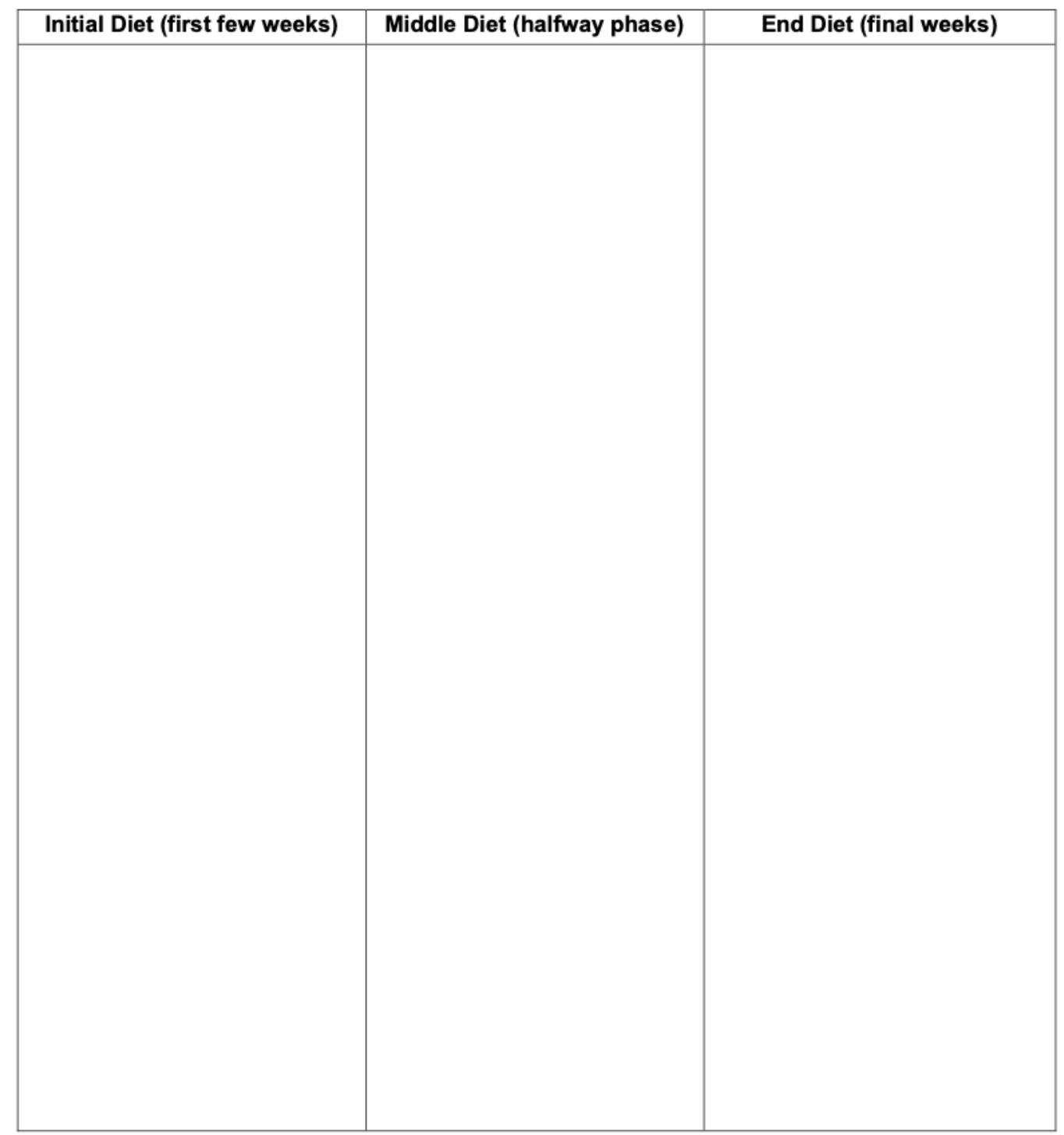

On average, how many refeed / cheat meals did you consume each week during competition prep (include what you ate and macros if possible. This does not include peak week).

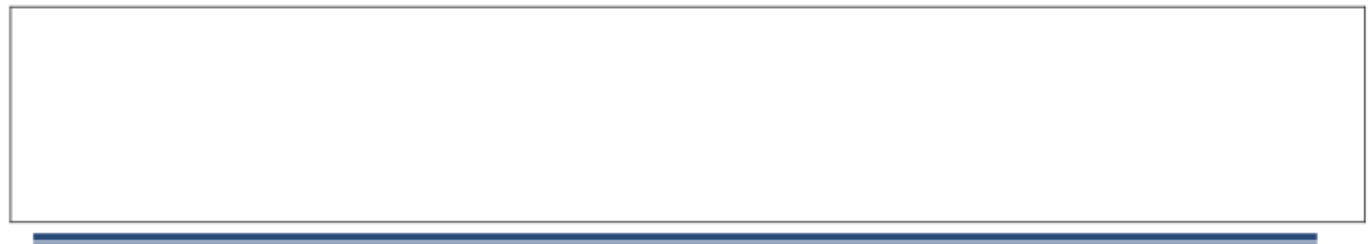

Dietary Assessment Questionnaire

Version 09.30.2020 Page 5 


\section{Peaking Strategies}

Please check ( $囚$ ) and provide additional detail where appropriate

\begin{tabular}{|l|l|l|}
\hline Peaking Strategy & check (囚) & $\begin{array}{l}\text { Details (food types, number of days, amount, } \\
\text { timing etc.) }\end{array}$ \\
\hline $\begin{array}{l}\text { No Peaking Strategy, } \\
\text { Regular Diet }\end{array}$ & & \\
\hline Carbohydrate depletion & & \\
\hline Carbohydrate loading & & \\
\hline Water loading & & \\
\hline Water depleting & & \\
\hline Sodium loading & & \\
\hline Sodium depleting & & \\
\hline Vitamin C or Citrus loading & & \\
\hline Other & & \\
\hline
\end{tabular}

\section{Contest Day Plan}

Please check $(\bowtie)$ and provide additional detail where appropriate

\begin{tabular}{|l|l|l|}
\hline Contest day strategy & $\begin{array}{c}\text { check } \\
(\mathbf{\otimes})\end{array}$ & $\begin{array}{c}\text { Details (food types, amount, timing } \\
\text { before stage, and brand) }\end{array}$ \\
\hline $\begin{array}{l}\text { High Gl/ sugary } \\
\text { carbohydrate pre stage }\end{array}$ & & \\
\hline Carbohydrate loading & & \\
\hline Fat loading & & \\
\hline Protein loading & & \\
\hline Regular diet & & \\
\hline use of alcohol & & \\
\hline use of sodium or salt foods & & \\
\hline Water depleting & & \\
\hline Minimal fiber & & \\
\hline Other & & \\
\hline
\end{tabular}

How long did you "pump up" before going on stage? 


\section{Resistance Training Program}

Please circle or highlight as appropriate

Resistance training at the start of competition preparation (first few weeks)

$\begin{array}{llllllll}\text { Number of resistance training sessions per week: } & 1 & 2 & 3 & 4 & 5 & 6 & 7+ \\ \text { Number of chest training sessions per week: } & 1 & 2 & 3 & 4 & 5 & 6 & 7+ \\ \text { Number of back training sessions per week: } & 1 & 2 & 3 & 4 & 5 & 6 & 7+ \\ \text { Number of leg training sessions per week: } & 1 & 2 & 3 & 4 & 5 & 6 & 7+ \\ \text { Number of exercises for chest, back, or quads: } & 1 & 2 & 3 & 4 & 5 & 6 & 7+ \\ \text { Typical sets per exercise for chest, back, or quads: } & 1 & 2 & 3 & 4 & 5 & 6 & 7+ \\ \text { Number of sets between 1 and 5 repetitions: } & 1 & 2 & 3 & 4 & 5 & 6 & 7+ \\ \text { Number of sets above 13 repetitions: } & 1 & 2 & 3 & 4 & 5 & 6 & 7+\end{array}$

\section{Resistance training in the middle of competition preparation (halfway phase)}

$\begin{array}{llllllll}\text { Number of resistance training sessions per week: } & 1 & 2 & 3 & 4 & 5 & 6 & 7+ \\ \text { Number of chest training sessions per week: } & 1 & 2 & 3 & 4 & 5 & 6 & 7+ \\ \text { Number of back training sessions per week: } & 1 & 2 & 3 & 4 & 5 & 6 & 7+ \\ \text { Number of leg training sessions per week: } & 1 & 2 & 3 & 4 & 5 & 6 & 7+ \\ \text { Number of exercises for chest, back, or quads: } & 1 & 2 & 3 & 4 & 5 & 6 & 7+ \\ \text { Typical sets per exercise for chest, back, or quads: } & 1 & 2 & 3 & 4 & 5 & 6 & 7+ \\ \text { Number of sets between 1 and 5 repetitions: } & 1 & 2 & 3 & 4 & 5 & 6 & 7+ \\ \text { Number of sets above 13 repetitions: } & 1 & 2 & 3 & 4 & 5 & 6 & 7+\end{array}$

\section{Resistance training at the end of competition preparation (final weeks)}

$\begin{array}{llllllll}\text { Number of resistance training sessions per week: } & 1 & 2 & 3 & 4 & 5 & 6 & 7+ \\ \text { Number of chest training sessions per week: } & 1 & 2 & 3 & 4 & 5 & 6 & 7+ \\ \text { Number of back training sessions per week: } & 1 & 2 & 3 & 4 & 5 & 6 & 7+ \\ \text { Number of leg training sessions per week: } & 1 & 2 & 3 & 4 & 5 & 6 & 7+ \\ \text { Number of exercises for chest, back, or quads: } & 1 & 2 & 3 & 4 & 5 & 6 & 7+ \\ \text { Typical sets per exercise for chest, back, or quads: } & 1 & 2 & 3 & 4 & 5 & 6 & 7+ \\ \text { Number of sets between 1 and 5 repetitions: } & 1 & 2 & 3 & 4 & 5 & 6 & 7+ \\ \text { Number of sets above 13 repetitions: } & 1 & 2 & 3 & 4 & 5 & 6 & 7+\end{array}$




\section{Cardiovascular Training Program}

Did you engage in fasted cardio?

\section{Start of competition preparation (first few weeks)}

Number of high intensity interval training (HIIT) or steady state cardio performed per week?

$\begin{array}{lllllllllll}\text { HIIT: } & 0 & 1 & 2 & 3 & 4 & 5 & 6 & 7 & 8 & \text { Other: }\end{array}$

Duration and any additional information:

$\begin{array}{lllllllllll}\text { Steady State: } & 0 & 1 & 2 & 3 & 4 & 5 & 6 & 7 & 8 & \text { Other: }\end{array}$

Duration and any additional information:

Habitual cardio sessions, example: walking to and from work, occupational cardio, etc.

$\begin{array}{llllllllllll}\text { Number of sessions: } & 0 & 1 & 2 & 3 & 4 & 5 & 6 & 7 & 8 & \text { Other: }\end{array}$

Duration and additional information:

\section{Middle of competition preparation (halfway phase)}

Did you engage in fasted cardio? Yes/ No

Number of high intensity interval training (HIIT) or steady state cardio performed per week?

$\begin{array}{lllllllllll}\text { HIIT: } & 0 & 1 & 2 & 3 & 4 & 5 & 6 & 7 & 8 & \text { Other: }\end{array}$

Duration and any additional information:

$\begin{array}{lllllllllll}\text { Steady State: } & 0 & 1 & 2 & 3 & 4 & 5 & 6 & 7 & 8 & \text { Other: }\end{array}$

Duration and any additional information:

Habitual cardio sessions, example: walking to and from work, occupational cardio, etc.

$\begin{array}{llllllllllll}\text { Number of sessions: } & 0 & 1 & 2 & 3 & 4 & 5 & 6 & 7 & 8 & \text { Other: }\end{array}$

Duration and additional information:

\section{End of competition preparation (final weeks)}

Did you engage in fasted cardio? Yes/ No

Number of high intensity interval training (HIIT) or steady state cardio performed per week?

$\begin{array}{lllllllllll}\text { HIIT: } & 0 & 1 & 2 & 3 & 4 & 5 & 6 & 7 & 8 & \text { Other: }\end{array}$

Duration and any additional information:

$\begin{array}{lllllllllll}\text { Steady State: } & 0 & 1 & 2 & 3 & 4 & 5 & 6 & 7 & 8 & \text { Other: }\end{array}$

Duration and any additional information:

Habitual cardio sessions, example: walking to and from work, occupational cardio etc.

$\begin{array}{llllllllllll}\text { Number of sessions: } & 0 & 1 & 2 & 3 & 4 & 5 & 6 & 7 & 8 & \text { Other: }\end{array}$

Duration and additional information:

End of Questionnaire

Dietary Assessment Questionnaire

Version 09.30.2020 Page 8 


\section{BIBLIOGRAPHY}

1. Bazzarre, T. L., Kleiner, S. M., \& Litchford, M. D. (1990). Nutrient intake, body fat, and lipid profiles of competitive male and female bodybuilders. Journal of the American College of Nutrition, 9(2), 136-142. doi:10.1080/07315724.1990.10720362

2. Chappell, A. J., \& Simper, T. N. (2018). Nutritional peak week and competition day strategies of competitive natural bodybuilders. Sports (Basel, Switzerland), 6(4), 126. https://doi.org/10.3390/sports6040126

3. Chappell, A. J., Simper, T., \& Barker, M. E. (2018). Nutritional strategies of high level natural bodybuilders during competition preparation. Journal of the International Society of Sports Nutrition, 15(1). doi:10.1186/s12970-0180209-Z

4. Chappell, A. J., Simper, T., \& Helms, E. (2019). Nutritional strategies of British professional and amateur natural bodybuilders during competition preparation. Journal of the International Society of Sports Nutrition, 16(1). doi:10.1186/s12970-019-0302-y

5. Gentil, P. (2015). A nutrition and conditioning intervention for natural bodybuilding contest preparation: Observations and suggestions. Journal of the International Society of Sports Nutrition, 12(1). doi:10.1186/s12970-015-

0111-X

6. Gentil, P., Lira, C. A., Paoli, A., Santos, J. A., Silva, R. D., Junior, J. R., Magosso, R. F. (2017). Nutrition, pharmacological and training strategies 
adopted by six bodybuilders: Case report and critical review. European Journal of Translational Myology, 27(1). doi:10.4081/ejtm.2017.6247

7. Helms, E. R., Aragon, A. A., \& Fitschen, P. J. (2014). Evidence-based recommendations for natural bodybuilding contest preparation: Nutrition and supplementation. Journal of the International Society of Sports Nutrition, 11(1). doi:10.1186/1550-2783-11-20

8. Iraki, J., Fitschen, P., Espinar, S., \& Helms, E. (2019). Nutrition recommendations for bodybuilders in the off-season: A narrative review. Sports (Basel, Switzerland), 7(7), 154. https://doi.org/10.3390/sports7070154

9. Ismaeel, A., Weems, S., \& Willoughby, D. S. (2018). A Comparison of the Nutrient Intakes of Macronutrient-Based Dieting and Strict Dieting Bodybuilders. International Journal of Sport Nutrition and Exercise Metabolism, 28(5), 502-508. doi:10.1123/ijsnem.2017-0323

10. Kleiner, S. M., Bazzarre, T. L., \& Ainsworth, B. E. (1994). Nutritional Status of Nationally Ranked Elite Bodybuilders. International Journal of Sport Nutrition, 4(1), 54-69. doi:10.1123/ijsn.4.1.54

11. Lambert, C. P., Frank, L. L., \& Evans, W. J. (2004). Macronutrient considerations for the sport of bodybuilding. Sports medicine (Auckland, N.Z.), 34(5), 317-327. https://doi.org/10.2165/00007256-200434050-00004

12. Lenzi, J. L., Teixeira, E. L., Jesus, G. D., Schoenfeld, B. J., \& Painelli, V. D. (2019). Dietary Strategies of Modern Bodybuilders During Different Phases of the Competitive Cycle. Journal of Strength and Conditioning Research, Publish Ahead of Print. doi:10.1519/jsc.0000000000003169 
13. Mitchell, L., Hackett, D., Gifford, J., Estermann, F., \& O’Connor, H. (2017). Do Bodybuilders Use Evidence-Based Nutrition Strategies to Manipulate Physique? Sports, 5(4), 76. doi:10.3390/sports5040076

14. Norton, L., (2020). Training the Physique Athlete: This is What Shredded Looks Like. Clean Health Fitness Institute. Retrieved from https://online.cleanhealth.edu.au/products/training-the-physiqueathlete/categories/2598041/posts/8669112

15. Pesta, D. H., \& Samuel, V. T. (2014). A high-protein diet for reducing body fat: mechanisms and possible caveats. Nutrition \& metabolism, 11(1), 53. https://doi.org/10.1186/1743-7075-11-53

16. Raina S. K. (2013). Limitations of 24-hour Recall Method: Micronutrient Intake and the Presence of the Metabolic Syndrome. North American Journal of Medical Sciences, 5(8), 498. https://doi.org/10.4103/1947-2714.117329

17. Roberts, B. M., Helms, E. R., Trexler, E. T., \& Fitschen, P. J. (2020). Nutritional Recommendations for Physique Athletes. Journal of Human Kinetics, 71(1), 79-108. doi:10.2478/hukin-2019-0096

18. Sandoval, W. M., \& Heyward, V. H. (1991). Food selection patterns of bodybuilders. International Journal of Sport Nutrition, 1(1), 61-68. https://doi.org/10.1123/ijsn.1.1.61

19. Schwarzenegger, A., \& Dobbins, B. (2014). The New Encyclopedia of Modern Bodybuilding. New York: Simon \& Schuster USA. 
20. Sedlock D. A. (2008). The latest on carbohydrate loading: a practical approach. Current Sports Medicine Reports, 7(4), 209-213. https://doi.org/10.1249/JSR.0b013e31817ef9cb

21. Slater, G., \& Phillips, S. M. (2011). Nutrition guidelines for strength sports: sprinting, weightlifting, throwing events, and bodybuilding. Journal of Sports Sciences, 29 Suppl 1, S67-S77. https://doi.org/10.1080/02640414.2011.574722

22. Spendlove, J., Mitchell, L., Gifford, J., Hackett, D., Slater, G., Cobley, S., \& O’Connor, H. (2015). Dietary Intake of Competitive Bodybuilders. Sports Medicine, 45(7), 1041-1063. doi:10.1007/s40279-015-0329-4

23. Wilson, J., \& Wilson, G. J. (2006). Contemporary issues in protein requirements and consumption for resistance trained athletes. Journal of the International Society of Sports Nutrition, 3(1), 7-27. https://doi.org/10.1186/1550-2783-3-1-7 